Article

\title{
Social Media Influence on Consumer Behavior: The Case of Mobile Telephony Manufacturers
}

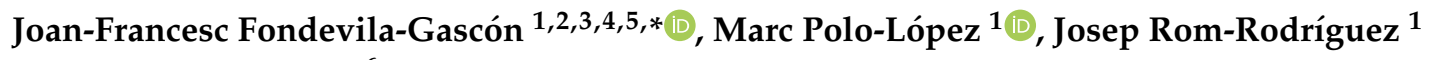 \\ and Pedro Mir-Bernal ${ }^{6}$ \\ 1 Advertising, Public Relations and Marketing Department, Blanquerna-Universitat Ramon Llull, \\ 08001 Barcelona, Spain; marcospl@blanquerna.url.edu (M.P.-L.); joseprr@blanquerna.url.edu (J.R.-R.) \\ 2 Communication, Pompeu Fabra University, 08002 Barcelona, Spain \\ 3 Cable Studies Center (CECABLE), 08221 Barcelona, Spain \\ 4 Communication Department, Centro Universitario Cesine, 39005 Santander, Spain \\ 5 Economy Department, University School Mediterrani-University of Girona, 08015 Barcelona, Spain \\ 6 ISEM Fashion Business School, University of Navarra, 28027 Madrid, Spain; pmir@unav.es \\ * Correspondence: joanfrancescfg@blanquerna.url.edu
}

Received: 27 December 2019; Accepted: 14 February 2020; Published: 18 February 2020

\begin{abstract}
Both broadband society and cloud journalism strengthen the use of social networks in order to achieve engagement between the brand and the end user. The various productive sectors try to optimize their online marketing strategies in networks in order to reach most of their potential audience. Such is the case of telecommunications sector, which is inherently linked with communication. With the aim of discovering social media influence on consumer behavior, in this quantitative research we analyze the use of social networks Facebook, YouTube, Twitter and Instagram by Samsung, Apple, Xiaomi and BQ as the axis of promotion of their products, increase of web traffic, improvement of the image of the company or the brand and obtaining brand notoriety. Bearing in mind that the mobile telephony sector is particularly competitive in Spain, it is concluded that the activity of mobile phone manufacturers in social media is positive, and, regarding consumer behavior, that no significant difference is detected between the average of ratings of the advertising of mobile telephony in the social networks, neither in the influence of the same by gender nor by age ranges.
\end{abstract}

Keywords: advertising; marketing; social media; consumer behavior; Facebook; YouTube; Twitter; Instagram; mobile telephony

\section{Introduction}

Social media are a fundamental axis for online marketing campaigns of most companies, focused on knowing the variables that condition the results of their campaigns in social media marketing (SMM), associated with natural or organic positioning or (search engine optimization (SEO). This axis has been an object of recent study as it is a source of technology transfer in the field of marketing. The aim of this research is to study social media influence on consumer behavior in the growing telecommunications sector, especially in mobile telephony manufacturers. The justification of this focus is the progressive competitive development of the telecom sector, traditionally based on public and monopolistic operators. With the liberalization process at the end of the 20th century, this market has changed deeply, thanks to the appearance of many competitors and greater activity for manufacturers. If we combine this process with the mobile phenomenon and with the consolidation of social networks as a way to connect with consumers, we can afford approaching a new view linking both concepts [1].

Mobile telephony companies represent a sector that invests more in advertising campaigns and is centered in the social media. Samsung and Apple are the market leaders, both in terms of share 
and advertising investment [2]. Xiaomi, third in the ranking, is a Chinese company that has become a commercial threat to Samsung, having cheaper mobile terminals. The Spanish BQ is also positioned at affordable prices.

Based on a quantitative methodology, the general objectives of the research consist of analyzing the advertising on social networks of four major reference companies of mobile telephony (Samsung, Apple, Xiaomi and BQ). The research gaps are a lack of data and evidence about strategies in the mobile telephony companies and the need of a comparative analysis to promote profitable and monetizable activity in this sector. As specific objectives, it is intended to review the concept, evolution and operation of advertising on social networks; observe and analyze the management model and the strategies of the mobile telephony companies chosen in social media; compare the different behaviors of each one of the companies analyzed in the different social media; try to discover similarities or differences in communication between the brands analyzed; obtain information to support decision making on the social media strategy of other companies; and analyze the impact of social networks on mobile phone companies.

\section{Theoretical Framework}

\subsection{Advertising on Social Networks}

The incursion of advertising on social networks has accelerated as the number of users of these networks has increased. In parallel, metrics have arisen that try to objectify the performance of the insertions [3,4], increasingly aimed at achieving a solid interactivity with the end user [5].

Communication in social media is modifying the way in which the businesses and their consumer behavior interact. Internet advertising incorporated new platforms and business opportunities for companies and brands. Although television leads advertising investment [6], the Internet is the medium that is growing the most. In addition, promotion in Social Media Marketing (SMM) is more effective in the long term [7] and creates a strong bond with clients because it reaches a participatory audience.

The main advantages of using ads on social media are as follows: the constant need for content creation (cloud journalism) can be profitable through the insertion of semantically related advertising (social journalism commerce); the monitoring is almost automatic; there is more flexibility in the ad formats; with a scarce investment, a great impact on customers can be achieved; cost per click (CPC) is lower compared to other advertising formats; it is easier to segment and find the target audience; you can create specific campaigns depending on demographic and socio-demographic data (sex, age, interests or business experience).

The monitoring factor is probably the addition most valued by the marketing areas of companies. Big data, in full 4.0 industry, is crossed with artificial intelligence to illuminate possible new campaigns focused on very specific targets. This helps to evaluate the results and to know the most loyal followers, from which potential configuration adjustments or improvements of future campaigns are revealed.

The growth of social networks is affecting traditional media and sectors such as tourism [8]. In the case of television, hybridization with social networks leads to an emerging standard, such as $\mathrm{HbbTV}$ in a broadband and interactivity framework [9-13]. Social media adds millions of audiences and, accordingly, receives more publicity. Personalization (customization) drives investments that are reduced in the classic media organizations [14].

The development of social networks generates, then, new possibilities of advertising communication. Entrepreneurially, in social networks it is discovered that power and productive capacity fall on individuals who spontaneously come together based on certain common interests [15].

As a comparison between different forms of social media and their ways of using communication, enterprises announce a product through social networks such as Instagram, Twitter, YouTube and Facebook, where brands act to control and improve their e-reputation by creating a partnership with a public character. Brands contact those brand prescribers, influencers or brand ambassadors to sponsor a product or service. This business strategy achieves maximum visibility with minimal investment [16]. 
Social network enterprises manage to make this new advertising format their main source of income through "collaborations". Followers are participants in each of the products they use or services they use. Their public profiles act as a platform for hundreds of non-traditional ads but with more effect than conventional advertising due to the relationship created between follower and influencer [17].

The most efficient and fastest way to turn a company into a viral one is with the previous selection and subsequent collaboration of a group of influencers. It is important to highlight the digital role of women, which is more profitable. This is due to the continuous advertising suggestion in Instagram or YouTube profiles, where the previous predisposition of female shopping becomes an opportunity for companies.

The analyzed phenomenon started with blogs [18], prior to networks such as Instagram, so they can be considered a first form of social media. Users trust the opinion of these bloggers if they want to buy a product [19]. Bloggers often impact on various networks (Instagram, Facebook, Twitter or YouTube). Brands look forward to collaborating with them to increase their visibility.

\subsection{Consumer Behaviour and Enterprise in Social Networks}

Internet and social networks transform the dynamics of social mobilization. The paper of the social environment is the consequence of a technological democracy. Passive reception has given way to an active, participatory connection. Users of social media publish a large amount of content on blogs and social networks, which helps to solve customer questions and make consumption decisions thanks to comments [20]. Social networks are seen as the best marketing tool possible [21].

Negative or positive mentions of a product or service, which were previously limited to a small environment, acquire on the Internet an impact that can reach millions of people. That is why the figures emerge of the prosumer, which brings its own values and proposals [22], and the crossumer, with a bonus of demand. In any case, the interest of the networks lies not so much in the contents as in their capacity to establish connections and value relationships [23].

The use of social networks in companies establishes the purposes of the use of social networks for the brand. Improvements in the image of the company or brand, greater brand notoriety and better promotion of products and services are detected.

The most common activities in social networks are the monitoring and analysis of comments, the measurement of indicators or KPIs of noneconomic returns and their use in advertising campaigns or actions. The use of social networks of companies focuses on Facebook, followed by Twitter, Instagram and YouTube. In these networks, products or services are promoted and web traffic is increased.

Regarding the analysis of consumer behavior, the willingness to spend can be very flexible and manageable. Telecom enterprises need to control some variables as priorities in order to keep the client satisfied, as triple-play or quintuple-play ones (TV services, fixed and mobile phone, fixed and mobile Internet) [24-27].

When reading so many good ratings in social networks [28], subscribers feel safe to go on with the trust in other's opinions and will start their relationship with the operator with good expectations already established. It is here where the operator has a main role, to offer what clients expect from them, especially postselling fast activity. If the operator fulfills their promises, clients' established expectations should stay at the same level or even be lower than the reality that they find; for example, in committed information rate (CIR), it is the percentage of broadband they need to obtain profit.

\subsection{Symbolic Consumption as One of the Main Driver in Telephony Purchase Behaviour}

The current consumer, following the postmodern vision that defines him as a hostage of consumption and identity, has raised consumer behavior into an important element of study of human behavior. The key role that consumption plays in our society has determined its main objective in understanding the purchase decision process [29], use and disposal [30,31], as well how to understand consumption as a continuous process of creating identity and group affiliation for the consumer [32,33]. 
Consumption stands out as a tool to solve functional needs, although these are no longer the main need to cover. The symbolic need has been the one that took the initiative and intends to create symbolic meaning around the individual to establish and/or maintain their identity, achieve acceptance and social distinction [34-36] or ratify group membership [37-41].

Faced with this reality, the postmodern consumer becomes a symbolic being who is only interested in the consumption of objects and/or experiences to appropriate the image, that is the meaning, and not the physical property of the product [42-44]. To achieve this, they accumulate previously selected sets of materials with a specific purpose to fulfil.

We must emphasize the difficulty involved in the fact that a single product or brand can build the entire narrative of an identity $[45,46]$. It is only achieved through a constellation of complementary products [47], which as a whole are symbolically complementary brands or products. The brands perceived as cultural icons of consumption differ from similar products and are carriers of cultural significance that goes beyond their physical characteristics, their functionality or their economic value, by proposing meanings or lifestyles that are shared socially by a society [48-50].

Brand manufacturers of mobile telephony, after creating the technological device that has penetrated the fastest in homes worldwide [51], have become true lovemarks with a high prominence in the life of the consumer from the functional, symbolic, and social perspectives in the broadband society and cloud journalism environment [52].

\section{Methodology}

These companies were chosen because it is considered that it would be interesting to compare the strategy of the two most famous brands (Samsung and Apple) with a foreigner that has been making a dent in our country (Xiaomi) and a Madrid local that has been growing little by little (BQ).

According to the objectives of the research, the hypotheses to be validated are the following, attending the trends observed in the scientific literature and the social networks activity of the manufacturers and operators in the telecommunications field:

H1. Social networks are one of the main advertising strategies for mobile phone manufacturers.

H2. The mobile phone manufacturers achieve the expected objectives in social networks.

H3. Advertising on social networks does not work equally for all mobile phone manufacturers.

H4. Social networks are an effective competitive tool for mobile phone companies.

H5. There is no correlation between sex and age and the impact of advertising on social networks for mobile phone manufacturers.

The methodology is quantitative, developed by emptying social network data and a survey. Thus, the social networks (Facebook, YouTube, Twitter and Instagram) of each company (Samsung, Apple, Xiaomi and BQ) were analyzed: profiles in general, figures, historical statistics and activity. The method of selection and structure was managed with the tools Like Alyzer, SocialBlade and Fanpage Karma. Likewise, a comparison of the followers of the companies in these networks was carried out. Through Social Mention, the mentions of the companies received in social networks during a specific month were analyzed.

In the survey on the impact of social networks on mobile telephone companies, only the answers of the respondents who use these networks were validated. The programs used were Google Drive, IBM SPSS (Statistical Package for the Social Sciences) Statistics and Microsoft Excel. This analysis was executed in phases. Thus, it started with an analysis by questions. Once the responses of the respondents that did not qualify were discarded, that is, those who do not use social networks, the survey was analyzed. The results obtained in each question of the survey could be analyzed in a general way. 
Inferential statistical tests were carried out looking for the relationship between the answers and gender and age. Using the Student's $t$-test for independent samples, the relationship between a quantitative variable and a qualitative variable was studied. In this case, two tests were carried out, one to relate the qualification of mobile phone advertising in social networks and gender and another to relate the assessment of the influence of social networks on the decision to purchase a mobile phone and the gender.

Finally, the analysis of the variance (ANOBA) of a factor was performed to observe the relationship between a quantitative variable and several categorical variables. Firstly, the relationship between the qualification of mobile phone advertising in social networks and each age range was analyzed, and secondly, the relationship between the assessments of the influence of social networks in the decision to purchase a mobile phone and the age ranges was analyzed.

\section{Results and Discussion}

\subsection{Statistical Descriptive Results}

When determining the followers of each mobile phone manufacturer company in the chosen social networks, sensible fluctuations are observed (Table 1). In the figures where Spain is indicated, the account is only for this country; when an official account appears, it refers to the official website of the brand and is not exclusive to Spanish users.

Table 1. Followers of mobile phone manufacturer enterprises in social networks.

\begin{tabular}{ccccc}
\hline Followers & Facebook & YouTube & Twitter & Instagram \\
\hline \multirow{2}{*}{ Samsung } & $156,577,540$ & 57,466 & 194,962 & 168,995 \\
& $($ Spain) & (Spain) & (Spain) & (Spain) \\
Apple & $11,306,781$ & 139,866 & $1,790,586$ & $4,853,287$ \\
& (Official) & (Spain) & (Official) & (Official) \\
Xiaomi & 187,150 & 145,894 & 31,202 & 16,387 \\
& $($ Spain) & (Official) & (Spain) & (Spain) \\
BQ & 139,368 & 24,915 & 89,934 & 16,852 \\
& (Official) & (Official) & (Official) & (Official) \\
\hline
\end{tabular}

Source: own elaboration based on data from Facebook, YouTube, Twitter and Instagram.

As each social network presents very different figures, the figures are transformed into percentages to facilitate comparisons (Figure 1).

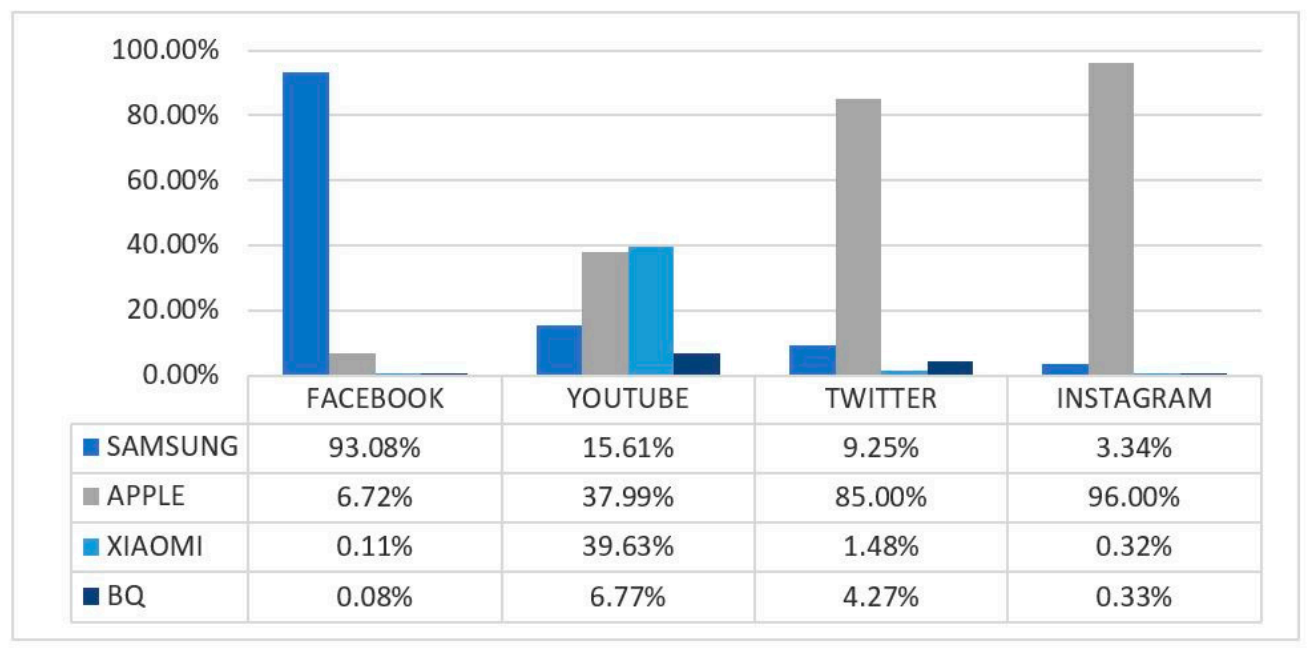

Figure 1. Percentage of followers of mobile telephony manufacturers in social networks. Source: own elaboration based on data from Facebook, YouTube, Twitter and Instagram. 
It can be seen that Apple leads the activity on Twitter and Instagram, and that on YouTube it approaches Xiaomi. On Facebook, however, it is far from Samsung. A probable cause is that on Facebook the account is exclusive for Spain. Samsung has accounts for Spain in all its networks, although it stands out in Facebook. Xiaomi stands out on YouTube, since in the rest of the networks, the accounts are exclusive for Spanish clients. BQ competes with Xiaomi Spain for penetrating the Spanish market and manages to surpass the Chinese brand on Twitter and Instagram.

In the survey carried out, of the 315 responses obtained, some users used no social networks ( $4.13 \%$, versus $95.87 \%$ who did use them). As thirteen individuals answered that they did not use social networks, they were eliminated from the sample, which was established at $n=302$.

Facebook $(88.41 \%)$ was the most-used social network (Figure 2), followed by Instagram $(81.13 \%)$, YouTube $(64.57 \%)$ and Twitter (38.41\%). Social networks such as LinkedIn, Pinterest, Snapchat, 21 Buttons, Tumblr, Litsy, Ask.fm and Goodreads (11.59\%) are located at a distance.

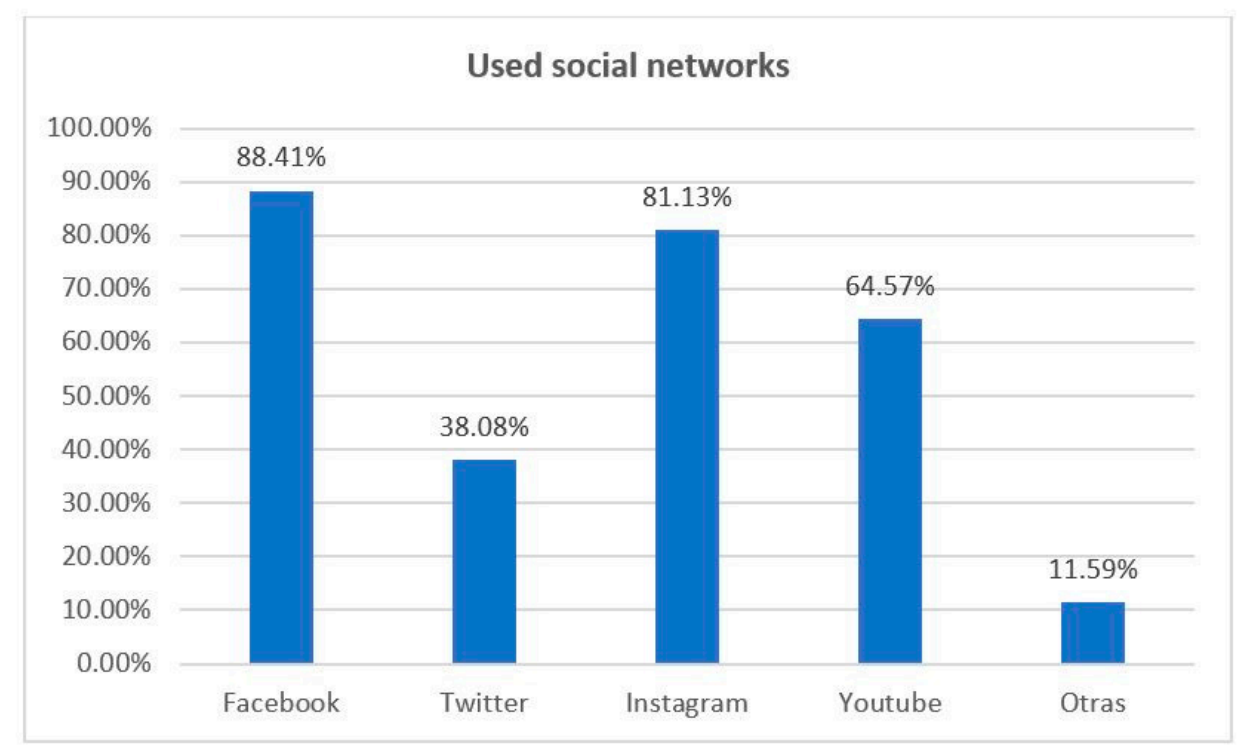

Figure 2. Social networks used by the sample. Source: own elaboration.

With regard to the mobile telephony brands that the respondents were shuffling (Figure 3), brands with a smaller number of users are grouped under the heading "Other" (7.28\%). Behind that group are BQ $(5.30 \%)$ and LG $(2.98 \%)$. At the head are three of the four main brands of research: Samsung (31.46\%), Apple (30.46\%), Huawei (14.24\%) and Xiaomi (8.28\%).

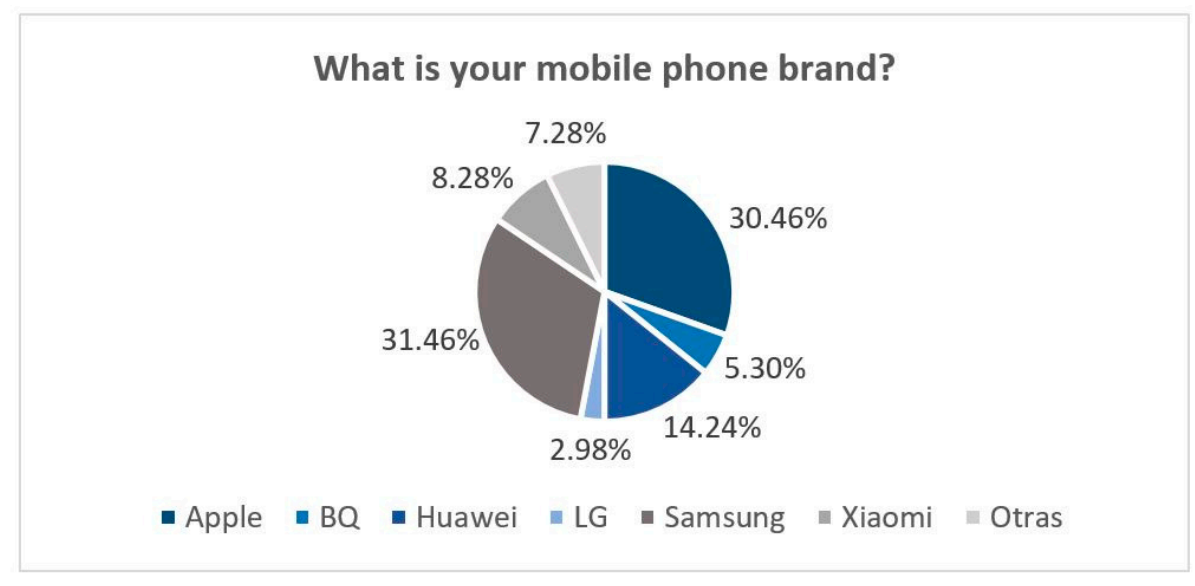

Figure 3. Mobile manufacturers used by the sample. Source: own elaboration. 
Among the respondents, the majority knew the mobile phone brands of Samsung (99.01\%) and Apple (92.38\%). BQ, despite being a Spanish brand, was not as well known $(68.21 \%)$. In contrast, Xiaomi, a Chinese brand with a shorter history in Spain, was known by $54.30 \%$ of respondents (Figure 4). We confirm H1 (social networks are one of the main advertising strategies for mobile phone manufacturers).

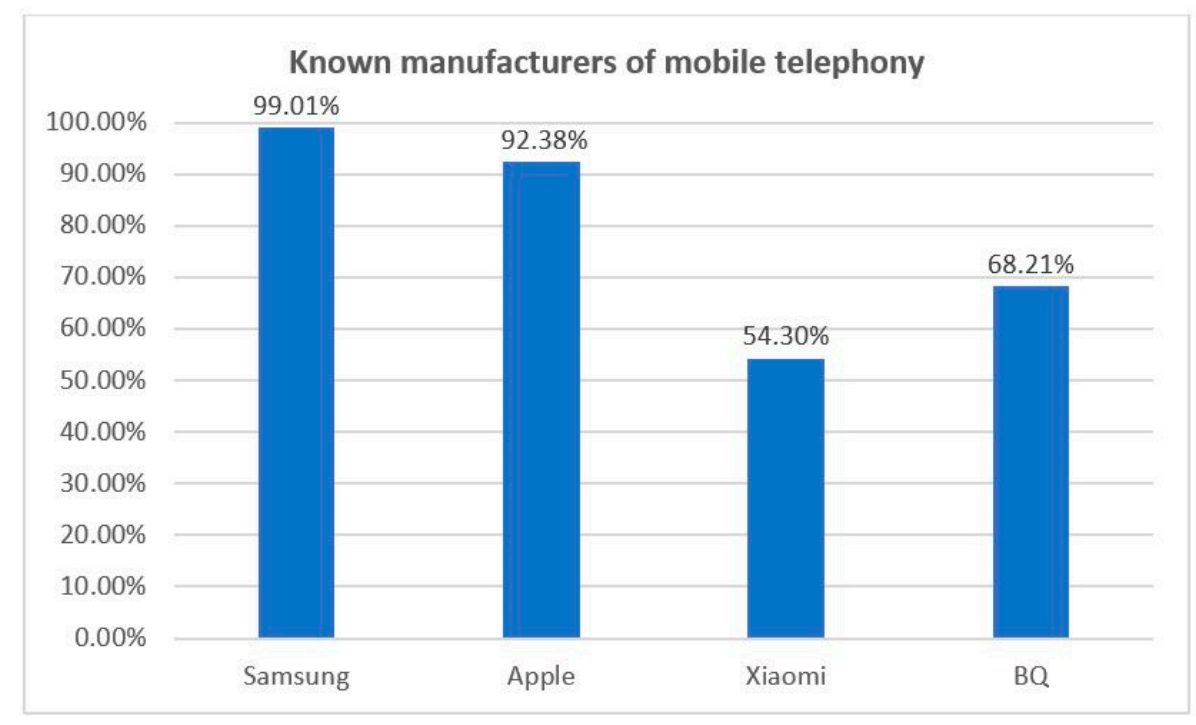

Figure 4. Mobile phone brands that respondents know. Source: own elaboration.

The factors that lead individuals to make the decision to buy are diverse (Figure 5). More than half $(53.31 \%)$ of the respondents consider that the quality of the product is fundamental, which distances this type of product from commoditization. Price (37.75\%), experience (33.11\%) with previous phones of the chosen brand and reviews on smartphone condition (20.20\%) contribute are also contributing factors. Next, the prestige of the brand (18.87\%) is located, referring to the quality-price ratio of previous mobiles. The advertising made by mobile brands convinces $2.65 \%$ of respondents. Finally, $1.32 \%$ take into account functionality, the experience of acquaintances, quality of camera and design of mobile. This confirms H3 (advertising on social networks does not work equally for all mobile phone manufacturers).

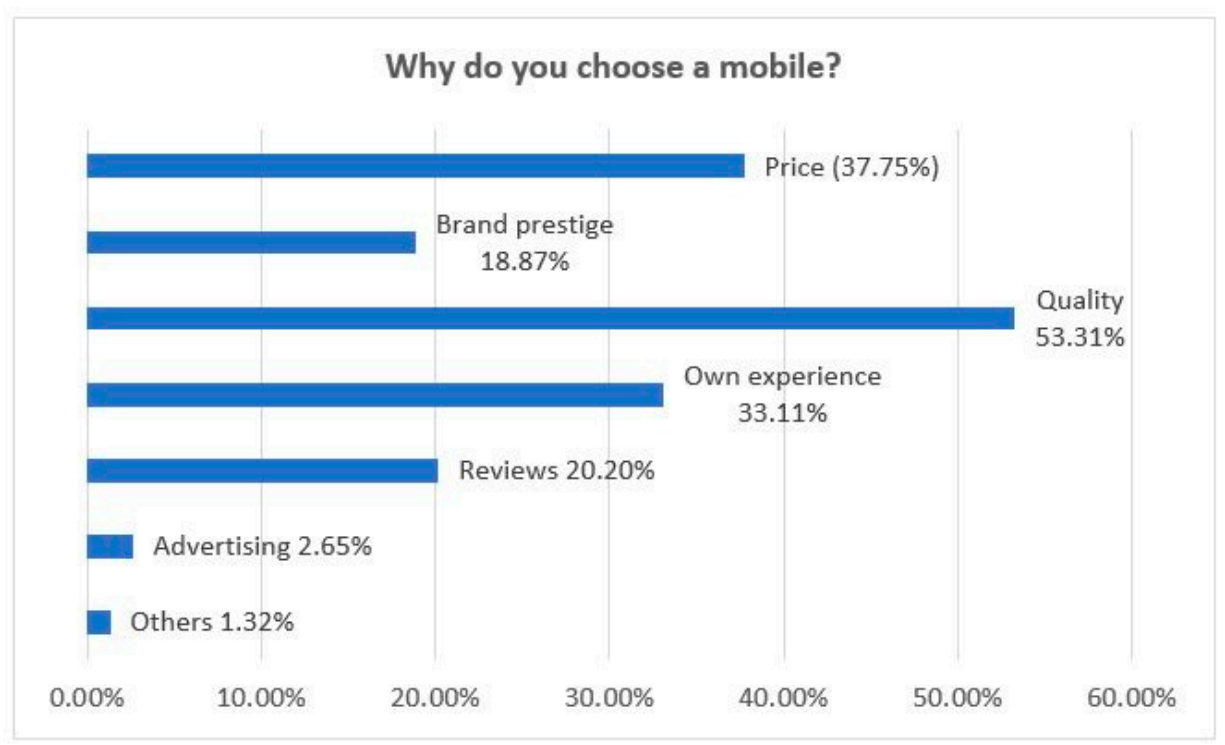

Figure 5. Factors that influence the purchase of a mobile. Source: own elaboration. 
One focus of valuation is the advertising of mobile telephony in social networks, using a 5-point Likert scale (Figure 6). Half (50\%) of the respondents rated those advertising inserts with a 3. 20.53\% opted for a $4,14.24 \%$ for a $2,10.60 \%$ for a 1 and $4.64 \%$ for a 5 . The average rating is 2.94 out of 5 , in a moderately satisfactory area. This confirms H2 (the mobile phone manufacturers achieve the expected objectives in social networks).

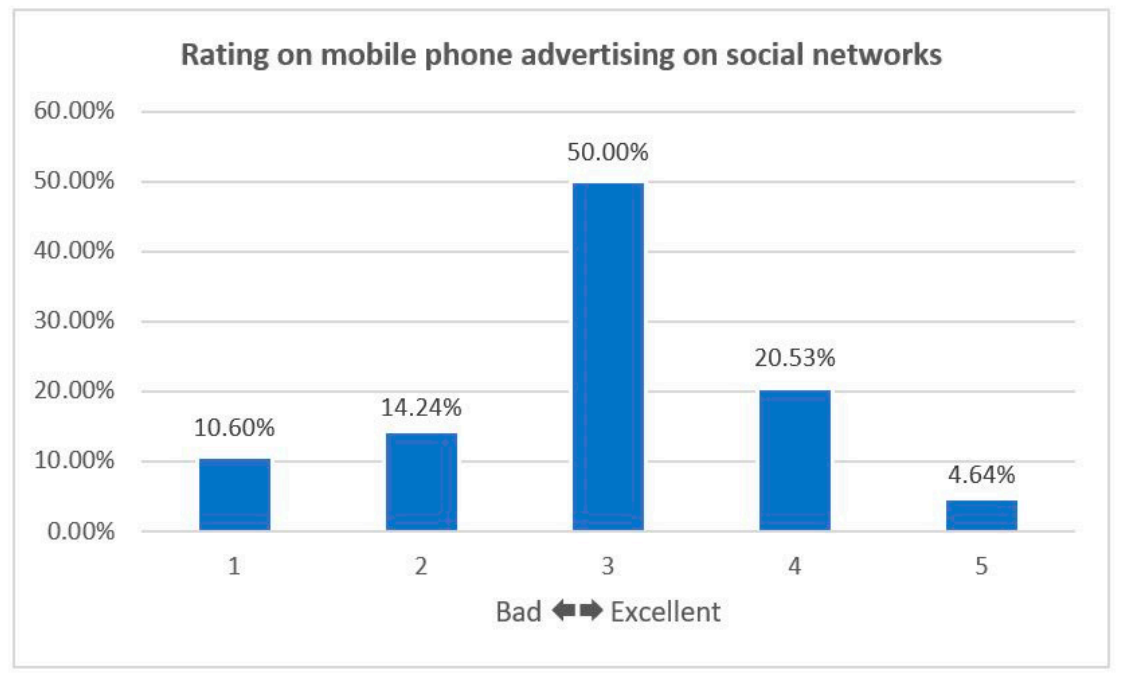

Figure 6. Rating on mobile phone advertising on social networks. Source: own elaboration.

On the influence of social networks in the decision to purchase a mobile phone, very little influence predominates $(38.41 \%)$, followed by an average influence $(25.50 \%)$. Here, $16.23 \%$ of respondents consider that there is little influence. For $13.91 \%$ of the sample there is a lot of influence and for $5.96 \%$ there is much influence when buying a mobile. The mean (2.33 out of 5 ) reflects a moderate influence (Figure 7). This refuses H4 (social networks are an effective competitive tool for mobile phone companies).

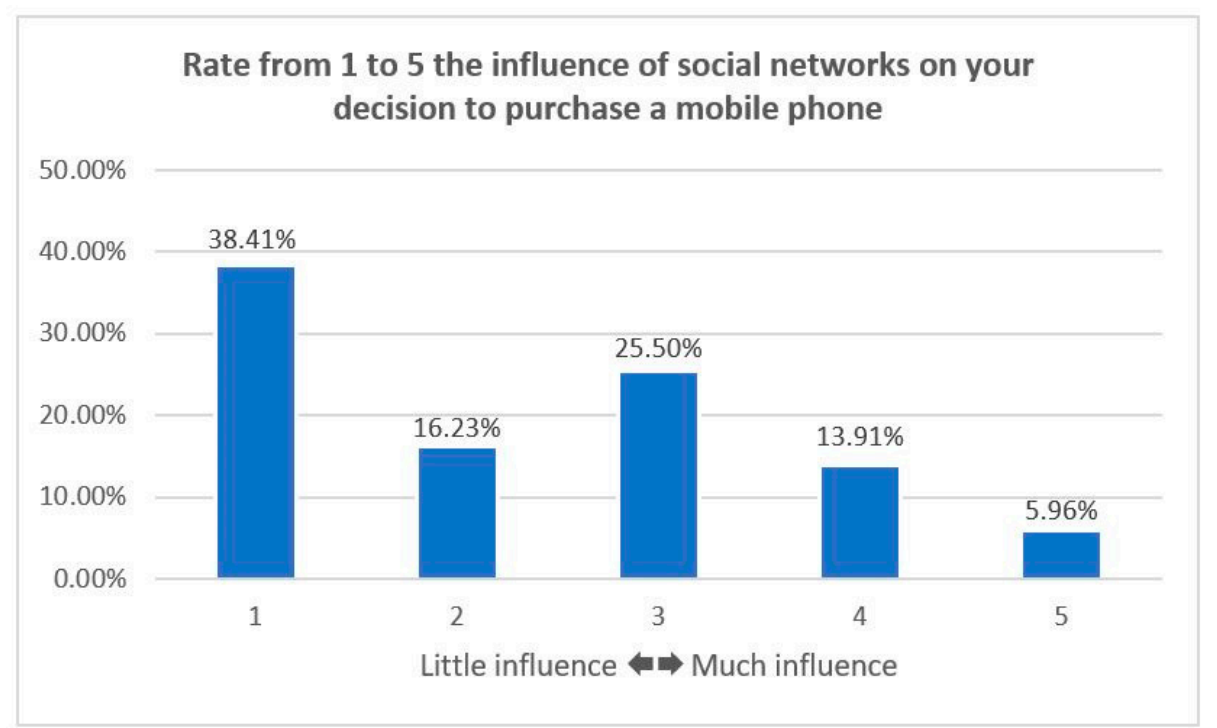

Figure 7. Influence of social networks in the decision to purchase a mobile. Source: own elaboration.

\subsection{Inferential Statistical Results}

When crossing the use of social networks and sex, it is observed that women use more Facebook $(32.33 \%)$ and Instagram (28.55\%). On YouTube and Twitter, men predominate (Figure 8 ). 


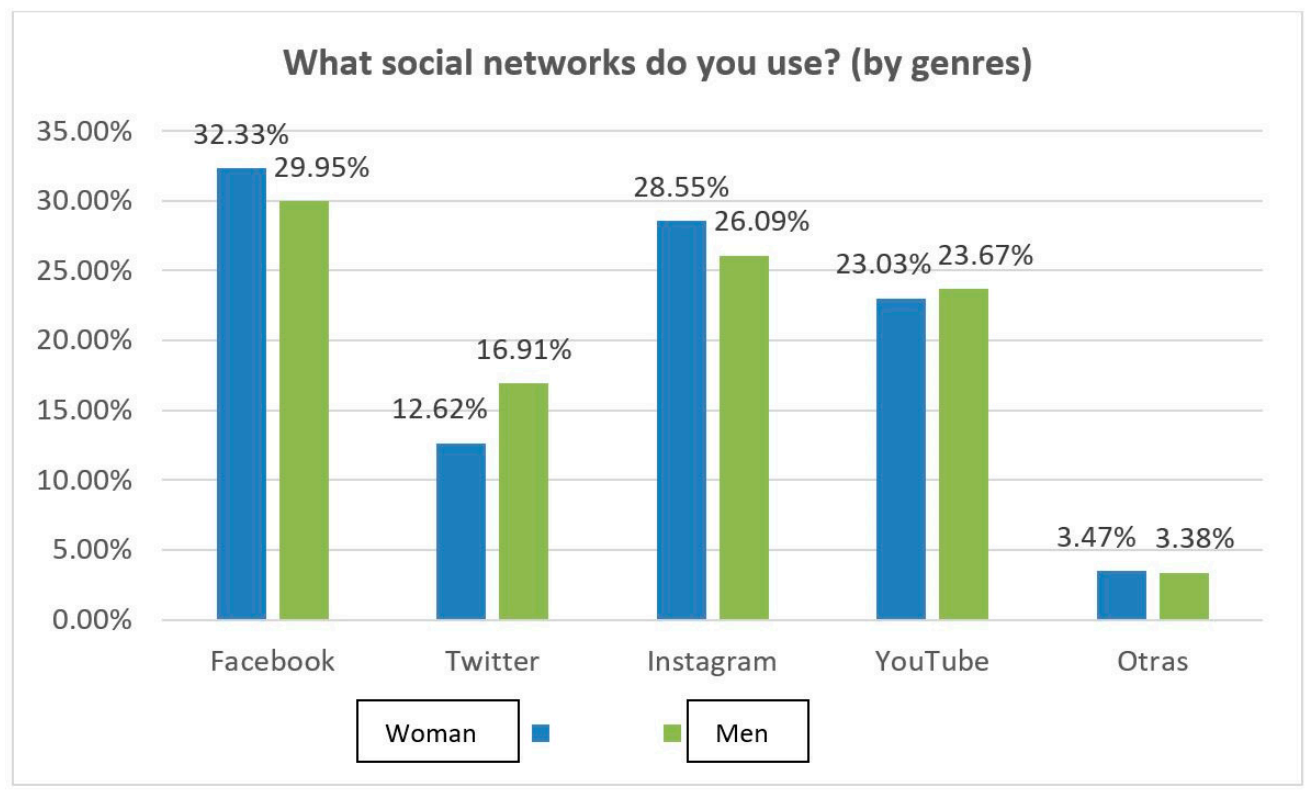

Figure 8. Relationship between gender and social networks used by respondents. Source: own elaboration.

Regarding the age factor, among young people under 18 years, more Instagram (37.25\%) and YouTube (33.33\%) are used. Respondents aged 19 to 29 prefer Facebook (29.82\%) and Instagram $(28.80 \%)$. In the age range of between 30 and 39 years, Facebook is preferred (32.26\%); and Twitter is scarcely used (14.81\%). People in the age group between 40 and 49 mostly use Facebook (36.99\%) and use very little Twitter (10.34\%). Facebook is highly used by the respondents of 50 or more years $(43.10 \%)$, while YouTube impacts to a lesser extent $(24.14 \%)$. The age factor determines the chosen social network: for older people it is Facebook, and for the younger ones, Instagram (Figure 9).

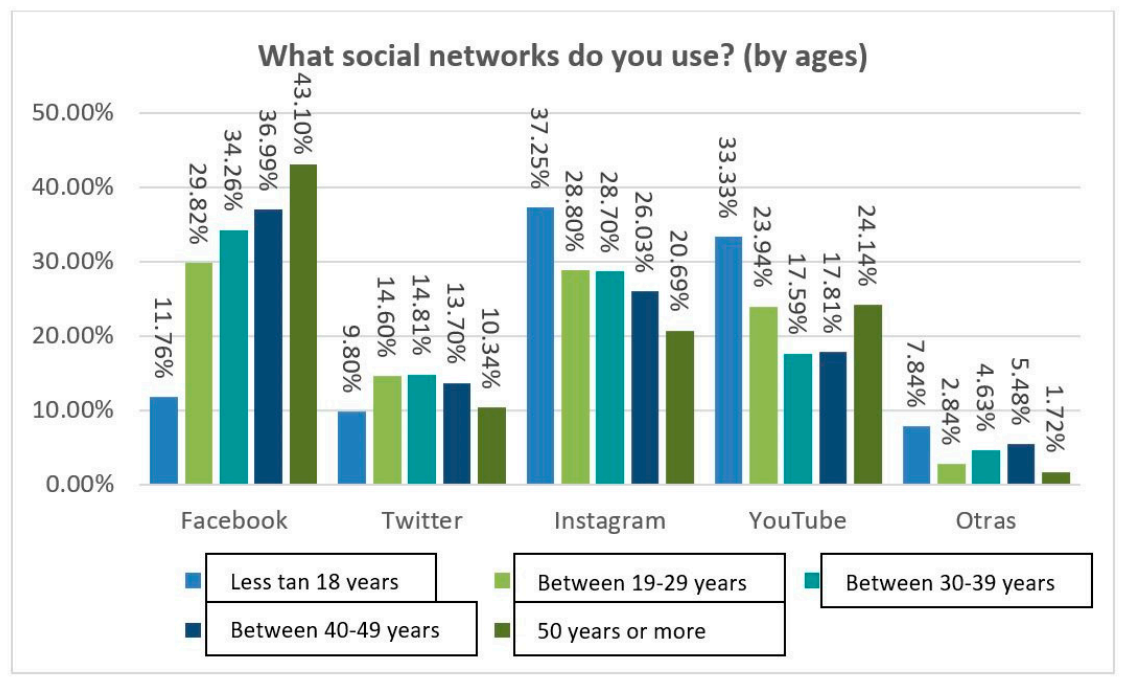

Figure 9. Relationship between age and social networks used by respondents. Source: own elaboration.

In the relationship between mobile phone type and gender, in the case of Apple there is a balance between men (31.94\%) and women (30\%), unlike Samsung (32.61\% women, $27.78 \%$ of men). In Huawei we can see that women trust more (15.65\%), and in Xiaomi, men $(12.50 \%)$. BQ is used by almost twice as many men surveyed $(8.33 \%)$ as women $(4.35 \%)$, while in LG, women predominate $(3.48 \%)$ before men (Figure 10). 


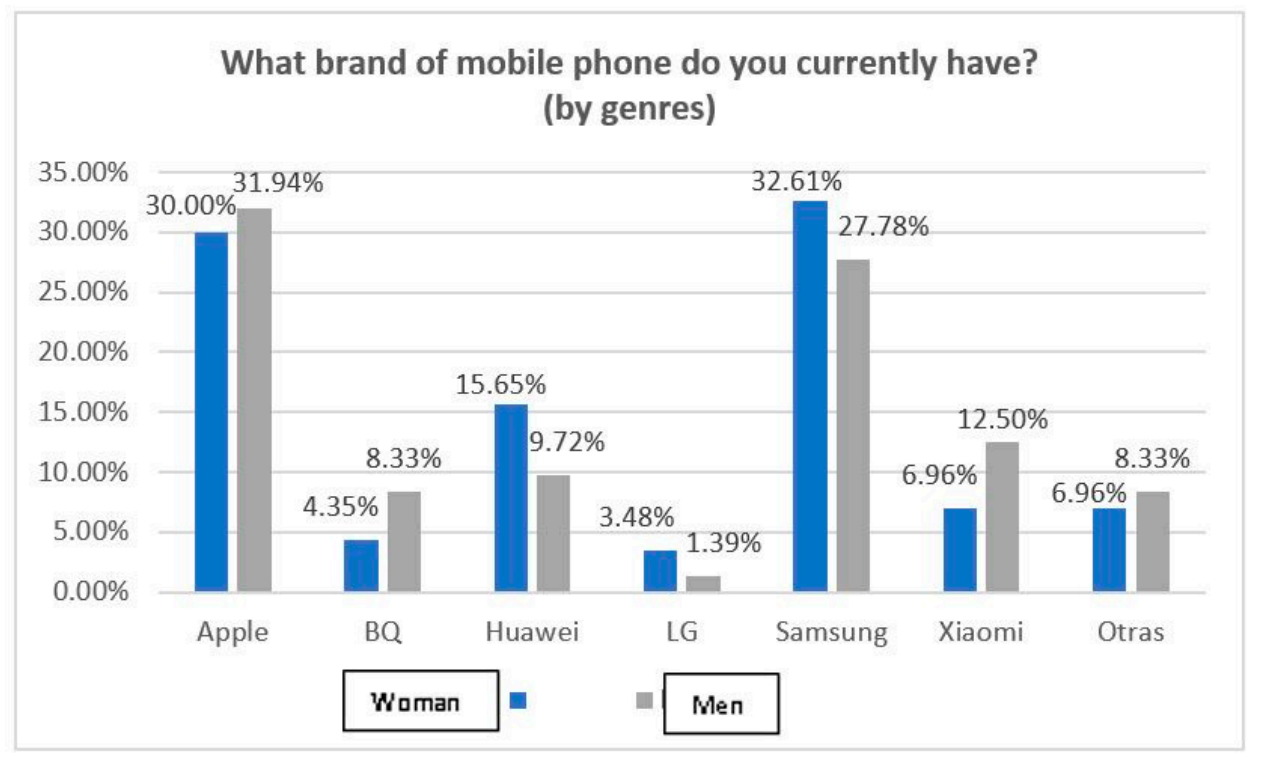

Figure 10. Relationship between gender and mobile brands of respondents. Source: own elaboration.

In terms of age, under-18 respondents choose Huawei (42.11\%) and Samsung (42.11\%) equally. Between 19 and 29 years, Apple (35.67\%) is the most commonly owned brand. On the other hand, Samsung (33.33\%) is preferred between 30 and 39 years old. In the ranges between 40 and 49 years and those of 50 or more, Samsung is chosen equally (with $44.83 \%$ ), followed by Apple (Figure 11).

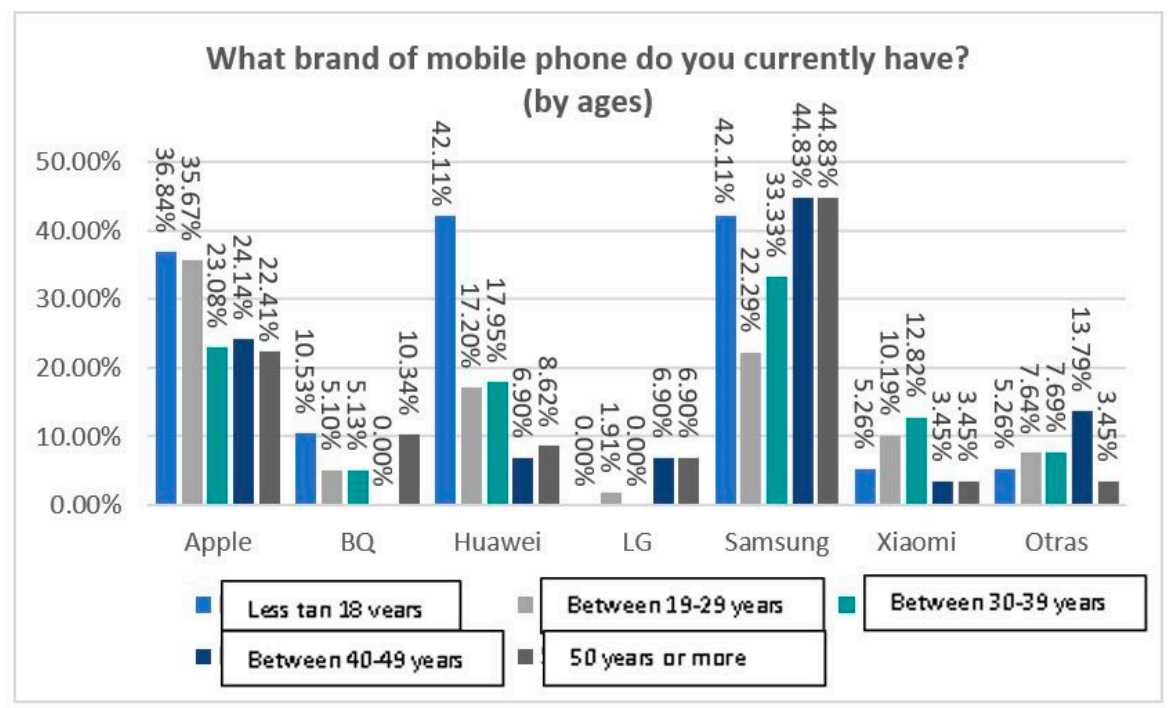

Figure 11. Relationship between age and mobile brands of respondents. Source: own elaboration.

When analyzing the degree of knowledge of a mobile phone, women know more about Samsung, Apple and BQ. In contrast, men show more knowledge of the Chinese brand Xiaomi $(20.99 \%$ of the men surveyed, $16.03 \%$ of women). Overall, Samsung is the best-known brand, and Xiaomi is close to the Spanish BQ (Figure 12).

By age, underage respondents know Samsung and Apple equally (29.23\%). In the range between 19 and 29 years, Samsung $(28.85 \%)$ and Apple (28.31\%) lead the ranking. Between 40 and 49 years old, the figures of the two protagonists coincide (32.18\%), while between 30 and 39 years Apple dominates slightly (Figure 13). Among the oldest, Samsung is in the lead (43.51\%). In the case of BQ, the youngest are those who have more knowledge about the brand $(26.15 \%)$. Xiaomi is best known among respondents in the 19-29 age bracket (19.85\%). 


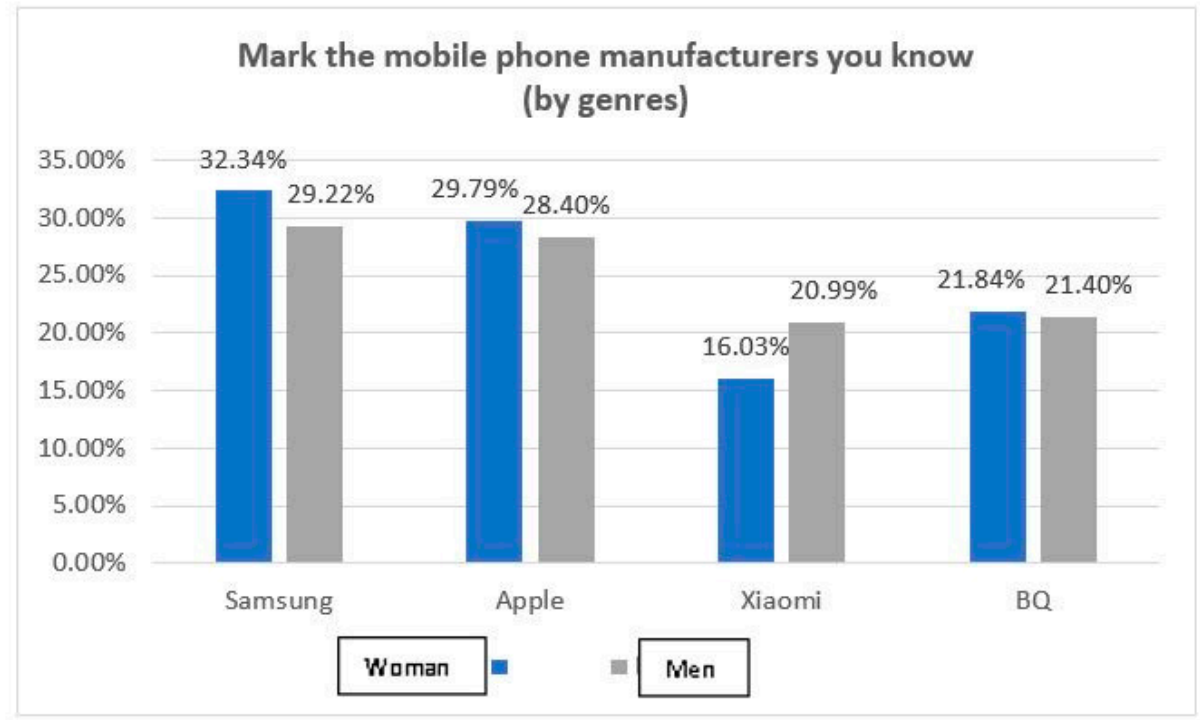

Figure 12. Relationship between gender and mobile phone brands that respondents know. Source: own elaboration.

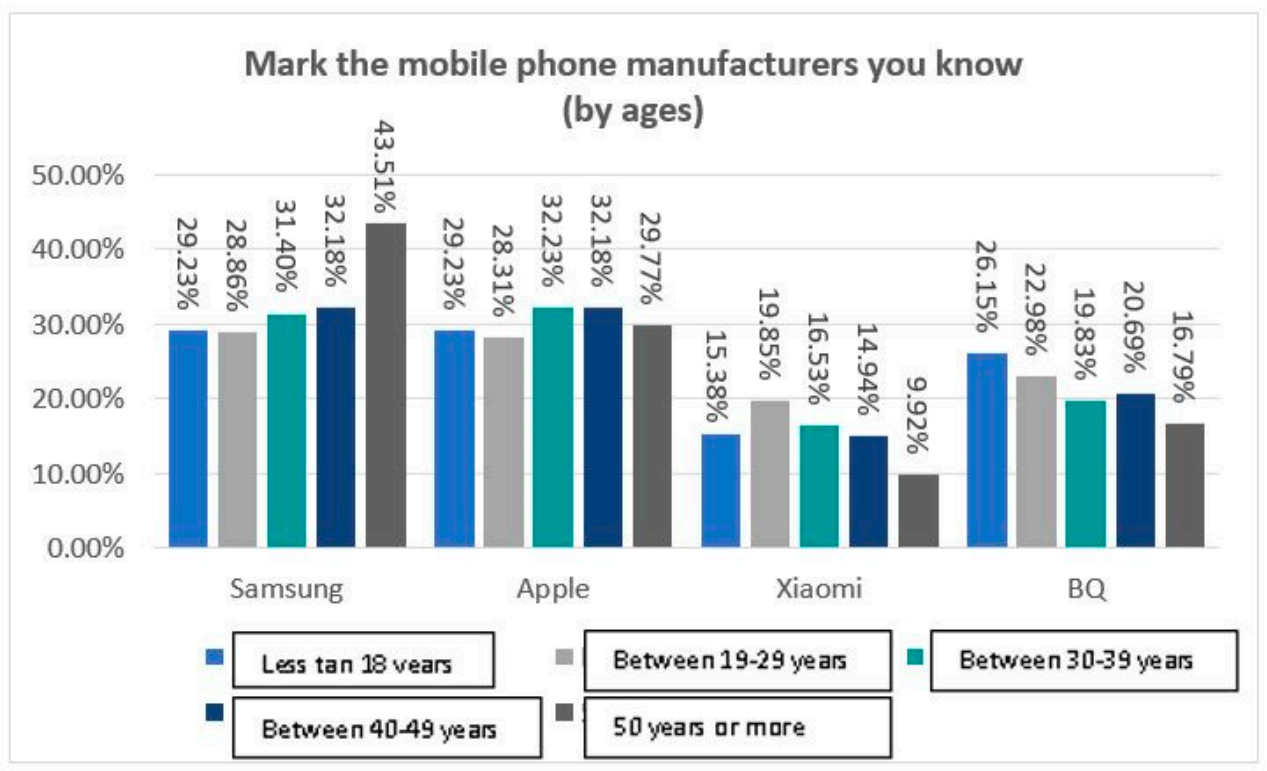

Figure 13. Relationship between age and mobile phone brands that respondents know. Source: own elaboration.

When analyzing purchasing factors, women are influenced by quality (32\%), price, experience, reviews, the prestige of the brand and, very residual, advertising $(1.87 \%)$, which in men impacts even less $(0.77 \%)$. In fact, in the masculine gender, the purchase motivation is led by the quality of the product $(31.54 \%)$, own experience $(20 \%)$ and the prestige of the brand $(14.62 \%)$. This last factor has less influence on women (10.13\%) (Figure 14).

When crossing purchasing criteria and age (Figure 15), it is observed that quality is the main factor, especially for individuals between 40 and 49 years old $(41.18 \%)$. The next factor in relevance is the price, which impacts especially the youngest $(27.27 \%)$ and the oldest $(27.03 \%)$. In third place is the experience itself. The contingent of 50 or more years is the one that is most guided by past experiences; the youngest ones $(6.82 \%)$ are not, probably because they have had fewer purchase options. The prestige of the brand is prioritized especially by those under $18(20.45 \%)$. Concerning the reviews, they are most important for people between 30 and 39 years old (13.79\%) and between 19 and 29 years 
old $(13.25 \%)$. Finally, advertising has a minimal influence on respondents under the age of 18 , between 19 and 29 years old and between 40 and 49 years old.

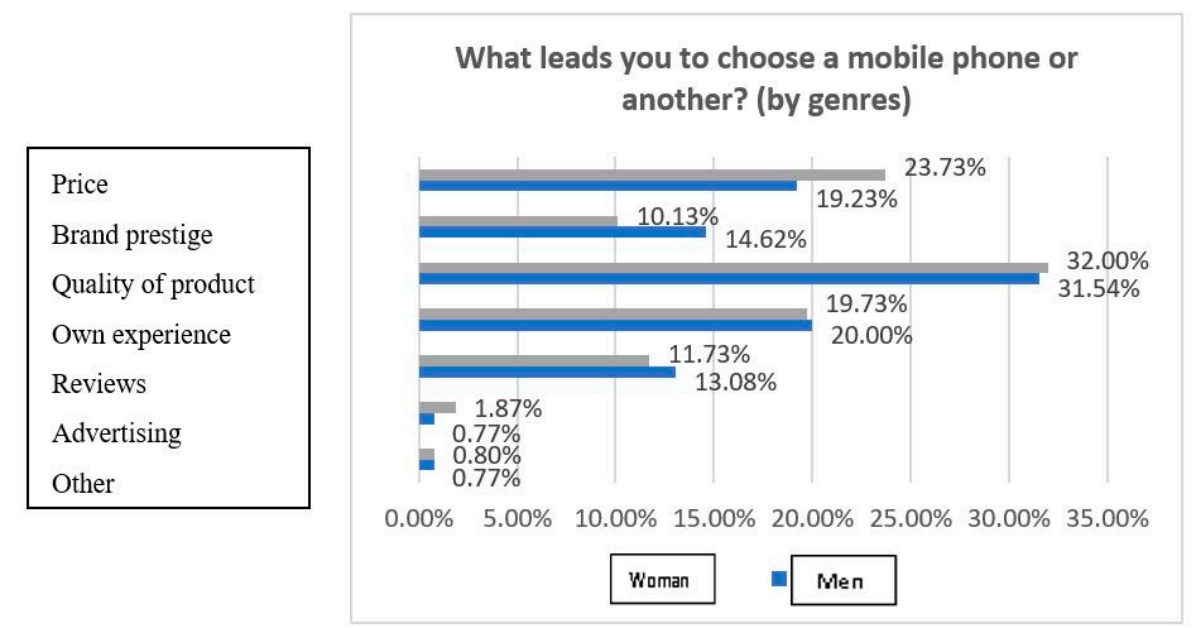

Figure 14. Relationship between gender and factors that influence the purchase of a mobile. Source: own elaboration.

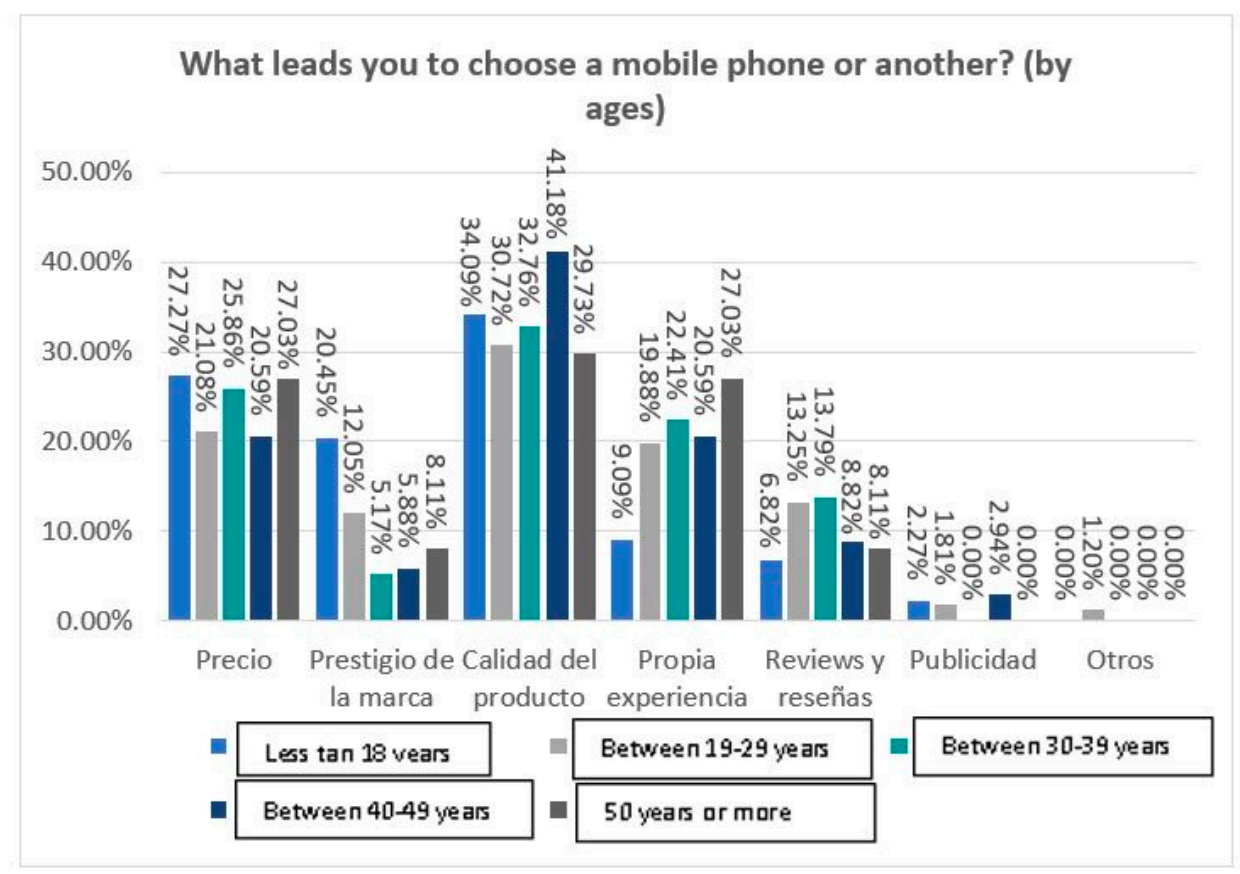

Figure 15. Relationship between age and factors that influence the purchase of a mobile. Source: own elaboration.

In terms of the relationship between gender and the rating of advertising on mobile telephony in social networks (Figure 16), the average score reflects that women score these promotional inserts with an average score of 2.95, similar to that of men (2.93).

In the advertising scores by age, it is observed that no child under 18 has established a score of 5 , although they are also the ones who have penalized the advertising practice the least. The age group that considers advertising to be the most excellent is that of the range between 30 and 39 years old $(6.90 \%)$. Those who are 40 to 49 years old are most likely to place blame. The youngest ones are located in the intermediate (Figure 17). Once the average rating given by each age range is calculated, the minors give the best score for advertising (3.05), ahead of individuals 50 years of age or older (2.59). 
Respondents between 19 and 29 years old give an average of 2.24, and those between 30 and 39 years old give 2.18. Those who give worst scores are those in the 40-49 age bracket (2.03).

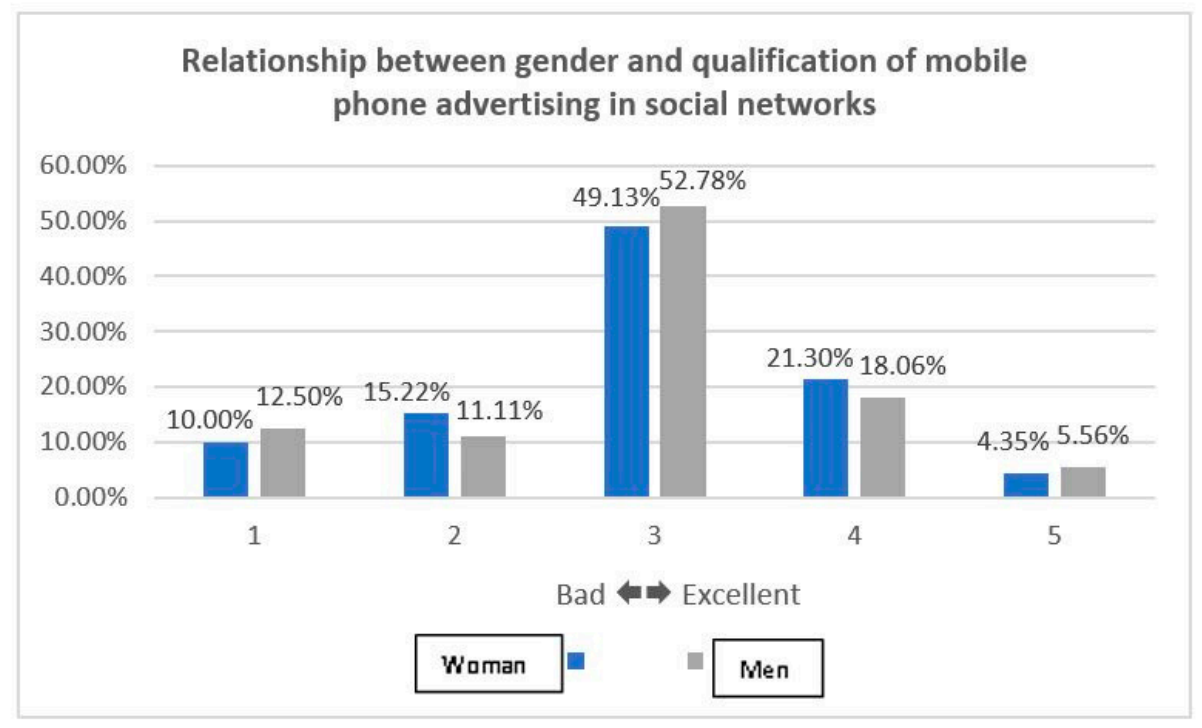

Figure 16. Relationship between gender and qualification of mobile phone advertising in social networks. Source: own elaboration.

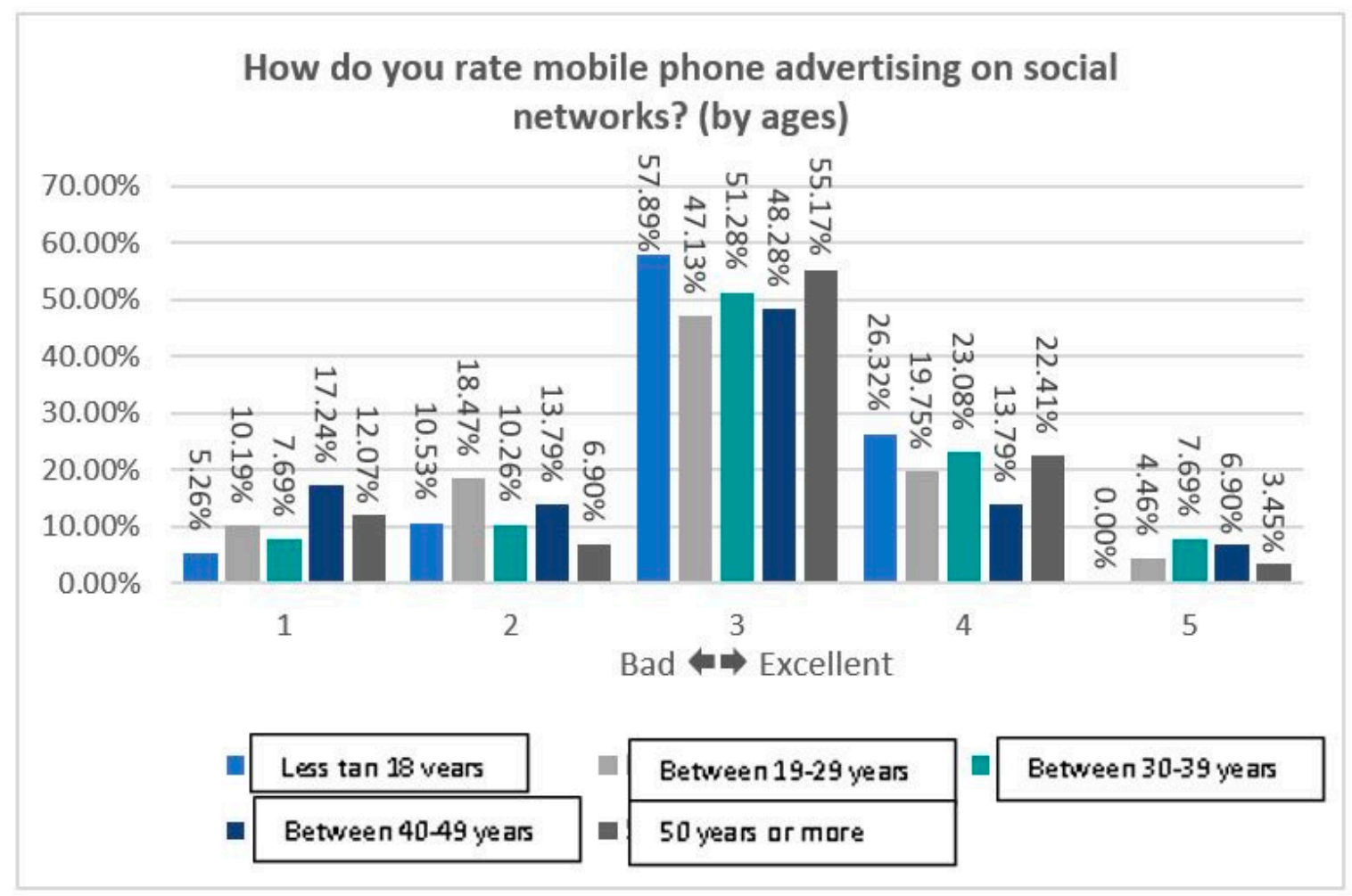

Figure 17. Relationship between age and qualification of mobile phone advertising in social networks. Source: own elaboration.

When analyzing the influence of social networks when buying a mobile phone, $40.28 \%$ of men argue that it affects them little, as do $37.83 \%$ of women (Figure 18). Among those considered highly influenced, men (6.94\%) slightly outnumber women (5.65\%). 


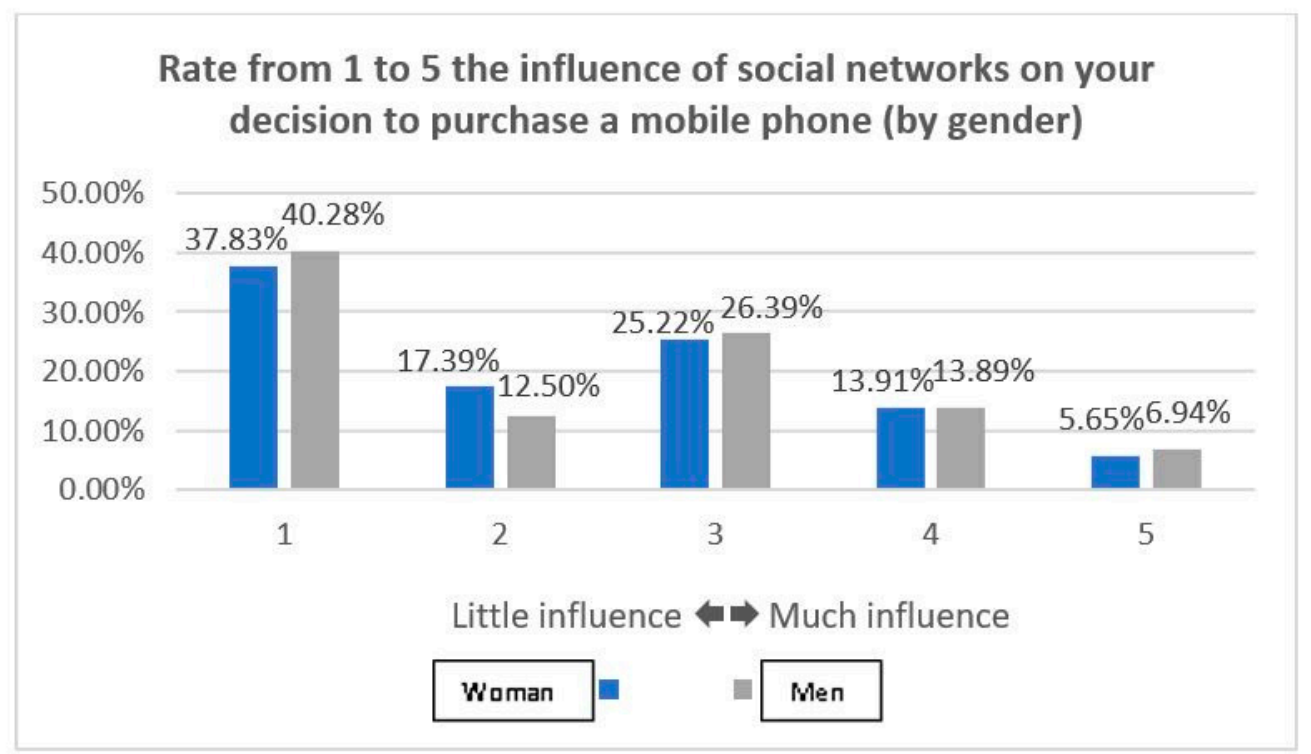

Figure 18. Relationship between gender and influence of social networks in the decision to purchase a mobile. Source: own elaboration.

By age, more than half of respondents between 40 and 49 years old (51.72\%) argue that social networks influence them very little to decide to buy a new smartphone, followed by respondents aged 19 to 29 (43, 95\%). In contrast, social networks have a greater influence on children under 18 years of age (10.53\% admit a lot of influence (Figure 19), twice as much as in the lowest influence range). In the neutrality zone are the majority of minors (36.84\%) and users between 30 and 39 years old $(33.33 \%)$, followed by those aged 50 or older $(29.31 \%)$.

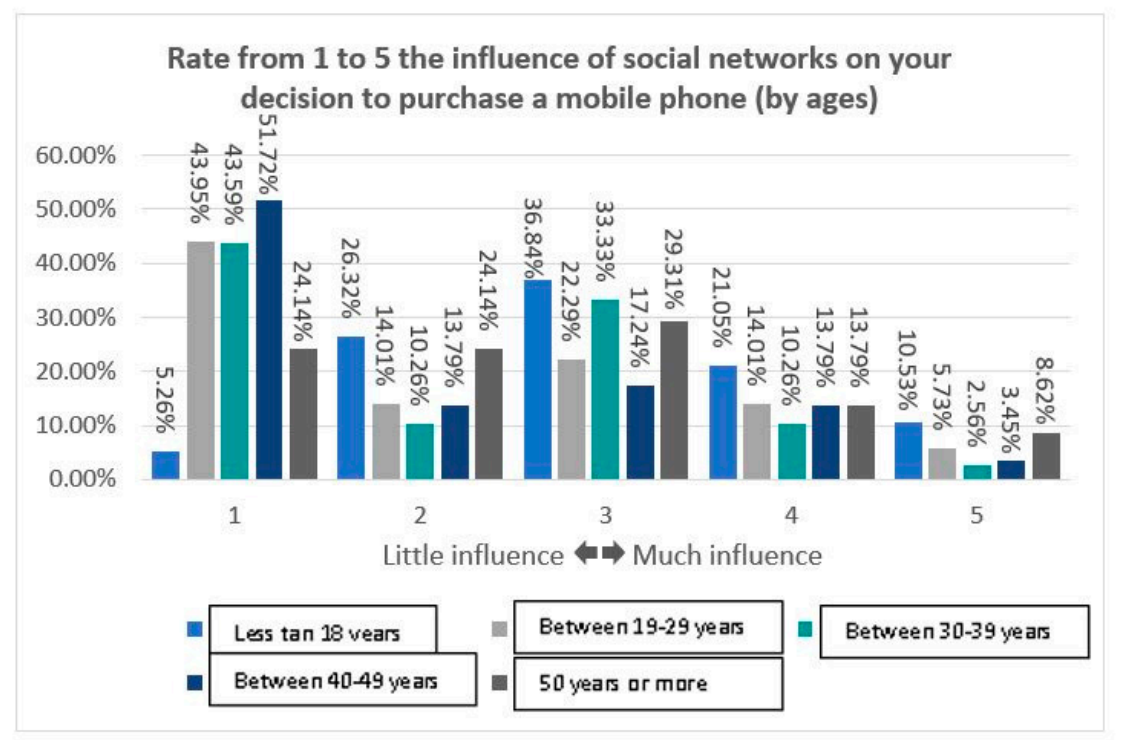

Figure 19. Relationship between age and influence of social networks in the decision to purchase a mobile. Source: own elaboration.

When applying the Student's $t$-test on the relationship between the qualification of mobile phone advertising in social networks and gender, the null hypothesis (H0) is that there is no significant difference between the average grades of mobile phone advertising in social networks in women and the average rating of mobile phone advertising in social networks in men. The alternative hypothesis $(\mathrm{H} 1)$ is that there is a significant difference between the average rating of mobile phone advertising 
in social networks in women and the average rating of mobile phone advertising in social networks in men.

In the group statistics it can be seen that the average of women (2.95) is higher than that of men (2.93), but it must be verified whether the difference is significant or due to chance (Table 2).

Table 2. Group statistics: ratings of mobile phone advertising on social networks and gender.

\begin{tabular}{lccccc}
\hline & Gender & $n$ & Mean & $\begin{array}{c}\text { Standard } \\
\text { Deviation }\end{array}$ & $\begin{array}{c}\text { Means of } \\
\text { Standard Error }\end{array}$ \\
\hline How do you rate mobile phone & Women & 230 & 2.95 & 0.970 & 0.064 \\
advertising on social networks? & Men & 72 & 2.93 & 1.012 & 0.119 \\
\hline \multicolumn{6}{c}{ Source: own elaboration. }
\end{tabular}

The determination level $\alpha$ (alpha) is $5 \%=0.05$. This level corresponds to the acceptable percentage of error in the statistical test. First, the test is performed to determine the normality between the results of the ratings. As it is a sample of $n=302$, the Kolmogorov-Smirnov results are considered (a nonparametric test that is used to determine the goodness of fit of two probability distributions with each other). The $p$-value of both cases is $>0.05(\alpha)$, with which $\mathrm{H} 0$ can be accepted, that is, the variable ratings in the two groups behave normally (Table 3 ).

Table 3. Tests of normality: qualifications of mobile phone advertising in social networks and gender.

\begin{tabular}{lccccccc}
\hline & \multirow{2}{*}{ Gender } & \multicolumn{2}{c}{ Kolmogorov-Smirnov $^{\text {a }}$} & \multicolumn{3}{c}{ Shapiro-Wilk $^{n}$} \\
\cline { 3 - 8 } & & Statistics & gl & Sig. & Statistics & gl & Sig. \\
\hline How do you rate mobile phone & Women & 0.269 & 230 & 0.000 & 0.882 & 230 & 0.000 \\
advertising on social networks? & Men & 0.291 & 72 & 0.000 & 0.866 & 72 & 0.000 \\
\hline
\end{tabular}

a: Significance correction of Lilliefors. Source: own elaboration.

In the Levene test (Table 4) we can observe how $p$-value $=0.904>\alpha=0.05$. Therefore, H0 is accepted (the variances are equal). Since equal variances have been assumed, the significance value of the $t$-test of 0.896 is considered. In the Student's $t$-test the $p$-value $=0.896>\alpha=0.05$. Therefore, we accept the null hypothesis ( $\mathrm{H} 0)$, according to which there is no significant difference between the average rating of mobile phone advertising in social networks in women and the average rating of mobile phone advertising in social networks in men. So, attending the results of Table 4, we refuse $\mathrm{H} 1$.

Regarding the relationship between the assessment of the influence of social networks on the decision to purchase a mobile phone and gender, the null hypothesis (H0) is that there is no significant difference between the mean of the assessment of the influence of social networks in the decision to purchase a mobile phone in women and the average value of the influence of social networks in the decision to purchase a mobile phone in men.

The alternative hypothesis (H1) is that there is a significant difference between the average value of the influence of social networks on the decision to purchase a mobile phone in women and the average value of the influence of social networks in the decision to buy a mobile phone in men.

The determination level $\alpha$ (alpha) $=5 \%=0.05$ corresponds to the acceptable error percentage in the statistical test. The test is performed to determine the normality between the results of the evaluations. As there is a big sample size, the results of Kolmogorov-Smirnov are taken in consideration. As $p$-value of both cases is $0.000>0.05(\alpha), \mathrm{H} 0$ can be accepted, which means that the variable values in the two groups behave normally (Table 5 ).

In the table of group statistics, it can be detected that the average of men (2.35) is higher than that of women (2.32), but it is necessary to check whether the difference is significant (Table 6). 
Table 4. Test of independent samples: ratings of mobile phone advertising in social networks and gender. Source: own elaboration.

\begin{tabular}{|c|c|c|c|c|c|c|c|c|c|c|}
\hline & & \multicolumn{2}{|c|}{$\begin{array}{c}\text { Levene Test of } \\
\text { Variance Quality }\end{array}$} & \multicolumn{7}{|c|}{$t$-Test for Equality of Means } \\
\hline & & \multirow[t]{2}{*}{$\mathbf{F}$} & \multirow[t]{2}{*}{ Sig. } & \multirow[t]{2}{*}{$t$} & \multirow[t]{2}{*}{ gl } & \multirow{2}{*}{$\begin{array}{c}\text { Sig. } \\
\text { (bilateral) }\end{array}$} & \multirow{2}{*}{$\begin{array}{l}\text { Difference } \\
\text { of Means }\end{array}$} & \multirow{2}{*}{$\begin{array}{l}\text { Difference of } \\
\text { Standard Error }\end{array}$} & \multicolumn{2}{|c|}{$\begin{array}{l}\text { 95\% Confidence Interval of } \\
\text { the Difference }\end{array}$} \\
\hline & & & & & & & & & Lower & Upper \\
\hline \multirow{2}{*}{$\begin{array}{l}\text { How do you rate } \\
\text { mobile phone } \\
\text { advertising on } \\
\text { social networks? }\end{array}$} & $\begin{array}{l}\text { Equal variances } \\
\text { are assumed }\end{array}$ & 0.014 & 0.904 & 0.131 & 300 & 0.896 & 0.017 & 0.132 & -0.243 & 0.278 \\
\hline & $\begin{array}{l}\text { Equal variances } \\
\text { are not assumed }\end{array}$ & & & 0.128 & 114.787 & 0.899 & 0.017 & 0.135 & -0.251 & 0.285 \\
\hline
\end{tabular}

Table 5. Tests of normality: valuations of the influence of social networks on the decision to purchase a mobile phone and gender.

\begin{tabular}{|c|c|c|c|c|c|c|c|}
\hline & \multirow{2}{*}{ Gender } & \multicolumn{3}{|c|}{ Kolmogorov-Smirnov $^{a}$} & \multicolumn{3}{|c|}{ Shapiro-Wilk } \\
\hline & & Statistic & gl & Sig. & Statistic & gl & Sig. \\
\hline Rate from 1 to 5 the influence of social networks on & Women & 0.230 & 230 & 0.000 & 0.853 & 230 & 0.000 \\
\hline your decision to purchase a mobile phone & Men & 0.248 & 72 & 0.000 & 0.842 & 72 & 0.000 \\
\hline
\end{tabular}

Table 6. Group statistics: valuations of the influence of social networks on the decision to purchase a mobile phone and gender.

\begin{tabular}{cccccc}
\hline & Genre & $n$ & Means & Standard Deviation & Means of Standard Error \\
\hline $\begin{array}{c}\text { Rate from } 1 \text { to } 5 \text { the influence of social networks on } \\
\text { your decision to purchase a mobile phone }\end{array}$ & Women & 230 & 2.32 & 1.265 & 0.083 \\
\cline { 2 - 6 } & Men & 72 & 2.35 & 1.323 & 0.156 \\
\hline
\end{tabular}


In the Levene test the $p$-value $=0.456>\alpha=0.05$. Thus, $\mathrm{H} 0$ is accepted (the variances are equal). We start from the significance value of Student's $t$-test, whose $p$-value $=0.883>\alpha=0.05$. Therefore, we accept the null hypothesis (H0), according to which there is no significant difference between the average value of the influence of social networks on the decision to purchase a mobile phone in women and the average of the assessment of the influence of social networks on the decision to purchase a mobile phone in men (Table 7).

The ANOVA analysis of a factor is also performed to see the relationship between a quantitative variable and several categorical ones. In the first place, the relationship between the qualification of mobile phone advertising in social networks and each age range will be analyzed, and then the relationship between the assessment of the influence of social networks on the decision to purchase a mobile phone and the age ranges.

In the relationship between the rating of mobile phone advertising in social networks and age, the null hypothesis $(\mathrm{H} 0)$ is that there are no differences between the rating of mobile phone advertising in social networks and the age ranges. The alternative hypothesis (H1) is that there are differences between the rating of mobile phone advertising in social networks and the age ranges.

The determination level $\alpha$ (alpha) $=5 \%=0.05$ corresponds to the acceptable error percentage willing in the statistical test. It can be observed (Table 8) that respondents between 30 and 39 years old are the ones who have rated advertising the best (average of 3.13). The most penalizing scores are from individuals between 19 and 29 years old (average of 2.90). It can also be observed that no child under 18 has given a grade of 5 , with 4 being the maximum grade.

The Levene variance homogeneity test indicates that $p$-value $=0.433>\alpha=0.05$, so there are no differences between variances (Table 9).

When there are no differences between the variances, we proceed to consider the ANOVA table, where it can be seen that $p$-value $=0.604>\alpha=0.05$. Therefore, the null hypothesis (H0) is accepted, according to which there are no differences between the rating of mobile telephony advertising in social networks and the age ranges (Table 10).

On the relationship between the assessment of the influence of social networks on the decision to purchase a mobile phone and age, the null hypothesis $(\mathrm{H} 0)$ is that there are no differences between the assessment of the influence of social networks in the decision of buying a mobile phone and the age ranges. The alternative hypothesis (H1) is that there are differences between the assessment of the influence of social networks on the decision to purchase a mobile phone and the age ranges.

With a determination level $\alpha$ (alpha) $=5 \%=0.05$, that is, the acceptable percentage of error in the statistical test, those under 18 are those who have best assessed the influence with an average score of 3.05. Those who scored worst are respondents between 40 and 49 years old with an average of 2.03 (Table 11). 
Table 7. Test of independent samples: valuations of the influence of social networks on the decision to purchase a mobile phone and gender

\begin{tabular}{|c|c|c|c|c|c|c|c|c|c|c|}
\hline & & \multicolumn{2}{|c|}{$\begin{array}{c}\text { Levene Test of } \\
\text { Variance Quality }\end{array}$} & \multicolumn{7}{|c|}{$t$-Test for Equality of Means } \\
\hline & & \multirow[t]{2}{*}{$\mathbf{F}$} & \multirow[t]{2}{*}{ Sig. } & \multirow[t]{2}{*}{$t$} & \multirow[t]{2}{*}{ gl } & \multirow{2}{*}{$\begin{array}{c}\text { Sig. } \\
\text { (bilateral) }\end{array}$} & \multirow{2}{*}{$\begin{array}{l}\text { Difference } \\
\text { of Means }\end{array}$} & \multirow{2}{*}{$\begin{array}{l}\text { Difference of } \\
\text { Standard Error }\end{array}$} & \multicolumn{2}{|c|}{$\begin{array}{l}\text { 95\% Confidence Interval of } \\
\text { the Difference }\end{array}$} \\
\hline & & & & & & & & & Lower & Upper \\
\hline \multirow{2}{*}{$\begin{array}{c}\text { How do you rate } \\
\text { mobile phone } \\
\text { advertising on } \\
\text { social networks? }\end{array}$} & $\begin{array}{l}\text { Equal variances } \\
\text { are assumed }\end{array}$ & 0.556 & 0.456 & -0.148 & 300 & 0.883 & -0.025 & 0.173 & -0.365 & 0.314 \\
\hline & $\begin{array}{l}\text { Equal variances } \\
\text { are not assumed }\end{array}$ & & & -0.144 & 114.498 & 0.886 & -0.025 & 0.177 & -0.376 & 0.325 \\
\hline
\end{tabular}

Table 8. Descriptive: ratings of mobile phone advertising on social networks and age ranges.

\begin{tabular}{|c|c|c|c|c|c|c|c|c|}
\hline \multicolumn{9}{|c|}{ How Do You Rate Mobile Phone Advertising on Social Networks? } \\
\hline & \multirow{2}{*}{$n$} & \multirow{2}{*}{ Media } & \multirow{2}{*}{\multicolumn{2}{|c|}{ StandardDeviation Standard Error }} & \multicolumn{2}{|c|}{ 95\% Confidence Interval for the Mean } & \multirow{2}{*}{ Min. } & \multirow{2}{*}{ Max } \\
\hline & & & & & Lower Limit & Upper Limit & & \\
\hline Less than 18 years & 19 & 3.05 & 0.780 & 0.179 & 2.68 & 3.43 & 1 & 4 \\
\hline Between 19 and 29 years & 157 & 2.90 & 0.982 & 0.078 & 2.74 & 3.05 & 1 & 5 \\
\hline Between 30 and 39 years & 39 & 3.13 & 0.978 & 0.157 & 2.81 & 3.45 & 1 & 5 \\
\hline Between 40 and 49 years & 29 & 2.79 & 1.114 & 0.207 & 2.37 & 3.22 & 1 & 5 \\
\hline 50 years or more & 58 & 2.98 & 0.964 & 0.127 & 2.73 & 3.24 & 1 & 5 \\
\hline Total & 302 & 2.94 & 0.978 & 0.056 & 2.83 & 3.05 & 1 & 5 \\
\hline
\end{tabular}

Source: own elaboration. 
Table 9. Proof of homogeneity of variances: qualifications of mobile phone advertising in social networks and age ranges.

\begin{tabular}{ccccc}
\hline \multicolumn{5}{c}{ How Do You Rate Mobile Phone Advertising on Social Networks? } \\
\hline Levene Statistic & df1 & df2 & Sig. \\
\hline 0.954 & 4 & 297 & 0.433 \\
\hline \multicolumn{4}{c}{ Source: own elaboration. }
\end{tabular}

Table 10. ANOVA: qualifications of advertising of mobile telephony on social networks and the age ranges.

\begin{tabular}{cccccc}
\hline \multicolumn{7}{c}{ How Do You Rate Mobile Phone Advertising on Social Networks? } \\
\hline & Sum of Squares & gl & Quadratic Means & F & Sig. \\
\hline Between groups & 2.626 & 4 & 0.656 & 0.683 & 0.604 \\
In groups & 285.417 & 297 & 0.961 & \\
Total & 288.043 & 301 & & \\
\hline \multicolumn{7}{c}{ Source: own elaboration. }
\end{tabular}

Table 11. Descriptive valuations of the influence of social networks on the decision to purchase a mobile phone and the age ranges.

\begin{tabular}{|c|c|c|c|c|c|c|c|c|}
\hline \multicolumn{9}{|c|}{ Rate from 1 to 5 the Influence of Social Networks on Your Decision to Purchase a Mobile Phone } \\
\hline & \multirow[t]{2}{*}{$n$} & \multirow[t]{2}{*}{ Media } & \multirow{2}{*}{$\begin{array}{l}\text { Standard } \\
\text { Deviation }\end{array}$} & \multirow{2}{*}{$\begin{array}{l}\text { Standard } \\
\text { Error }\end{array}$} & \multicolumn{2}{|c|}{$\begin{array}{c}95 \% \text { Confidence Interval } \\
\text { of the Difference }\end{array}$} & \multirow[t]{2}{*}{ Min. } & \multirow[t]{2}{*}{ Max. } \\
\hline & & & & & $\begin{array}{l}\text { Lower } \\
\text { Limit }\end{array}$ & $\begin{array}{l}\text { Upper } \\
\text { Limit }\end{array}$ & & \\
\hline Less than 18 years & 19 & 3.05 & 1.079 & 0.247 & 2.53 & 3.57 & 1 & 5 \\
\hline Between 19 and 29 years & 157 & 2.24 & 1.302 & 0.104 & 2.03 & 2.44 & 1 & 5 \\
\hline Between 30 and 39 years & 39 & 2.18 & 1.189 & 0.190 & 1.79 & 2.56 & 1 & 5 \\
\hline Between 40 and 49 years & 29 & 2.03 & 1.267 & 0.235 & 1.55 & 2.52 & 1 & 5 \\
\hline 50 years or more & 58 & 2.59 & 1.243 & 0.163 & 2.26 & 2.91 & 1 & 5 \\
\hline Total & 302 & 2.33 & 1.277 & 0.073 & 2.18 & 2.47 & 1 & 5 \\
\hline
\end{tabular}

The Levene variance homogeneity test indicates that $p$-value $=0.197>\alpha=0.05$, so there are no differences between variances (Table 12).

Table 12. Proof of homogeneity of variances: valuations of the influence of social networks in the decision to purchase a mobile phone and the age ranges.

\begin{tabular}{cccc}
\hline \multicolumn{4}{c}{ Rate from $\mathbf{1}$ to $\mathbf{5}$ the Influence of Social Networks on Your Decision to Purchase a Mobile Phone } \\
\hline Levene Statistic & df1 & df2 & Sig. \\
\hline 1.517 & 4 & 297 & 0.197 \\
\hline \multicolumn{4}{c}{ Source: own elaboration. }
\end{tabular}

As there are no differences between the variances, the ANOVA table is considered, where it is observed that $p$-value $=0.022>\alpha=0.05$. Therefore, the null hypothesis (H0) is rejected and the alternative hypothesis (H1) is accepted, according to which there are differences between any of the groups in the assessment of the influence of social networks on the decision to purchase a mobile phone and the age ranges (Table 13). 
Table 13. ANOVA: valuations of the influence of social networks on the decision to purchase a mobile phone and the age ranges.

\begin{tabular}{cccccc}
\hline \multicolumn{5}{c}{ Rate from $\mathbf{1}$ to $\mathbf{5}$ the Influence of Social Networks on } & Your Decision to Purchase a Mobile Phone \\
\hline & Sum of Squares & gl & Quadratic Means & F & Sig. \\
\hline Between groups & 18.541 & 4 & 4.635 & 2.917 & 0.022 \\
In groups & 472.006 & 297 & 1.589 & \\
Total & 490.546 & 301 & & & \\
\hline \multicolumn{7}{c}{ Source: own elaboration. }
\end{tabular}

To determine in which groups there are differences, the Tukey post-hoc test is performed (Table 14). In this test it can be observed that, with a confidence level of $95 \%$, there is no group with a $p$-value less than $0.05(\alpha)$, with which it can finally be concluded that there are no significant differences between the groups of assessment of the influence of social networks on the purchase decision and the age ranges (H1). This confirms H5 (there is no correlation between sex and age and the impact of advertising on social networks for mobile phone manufacturers).

Table 14. Multiple comparisons-Valuations of the influence of social networks on the decision to purchase a mobile phone and the age ranges.

\begin{tabular}{|c|c|c|c|c|c|c|}
\hline \multicolumn{7}{|c|}{ Dependent Variable: Rate from 1 to 5 the Influence of Social Networks on Your Decision to Buy a Mobile Phone } \\
\hline \multirow{3}{*}{ (I) Age } & \multicolumn{4}{|c|}{ HSD Tukey } & & \\
\hline & \multirow[t]{2}{*}{ (J) Age } & \multirow{2}{*}{$\begin{array}{c}\text { Means } \\
\text { Difference } \\
\text { (I-J) }\end{array}$} & \multirow{2}{*}{$\begin{array}{l}\text { STANDARD } \\
\text { ERROR }\end{array}$} & \multirow[t]{2}{*}{ Sig. } & \multicolumn{2}{|c|}{$\begin{array}{l}95 \% \text { Confidence Interval of } \\
\text { the Difference }\end{array}$} \\
\hline & & & & & Lower Limit & Upper Limit \\
\hline \multirow{4}{*}{$\begin{array}{l}\text { Less than } 18 \\
\text { years }\end{array}$} & Between 19 and 29 years & 0.817 & 0.306 & 0.061 & -0.02 & 1.66 \\
\hline & Between 30 and 39 years & 0.873 & 0.353 & 0.099 & -0.09 & 1.84 \\
\hline & Between 40 and 49 years & 1.018 & 0.372 & 0.051 & 0.00 & 2.04 \\
\hline & 50 years or more & 0.466 & 0.333 & 0.628 & -0.45 & 1.38 \\
\hline \multirow{4}{*}{$\begin{array}{l}\text { Between } 19 \\
\text { and } 29 \text { years }\end{array}$} & Less than 18 years & -0.817 & 0.306 & 0.061 & -1.66 & 0.02 \\
\hline & Between 30 and 39 years & 0.056 & 0.226 & 0.999 & -0.56 & 0.68 \\
\hline & Between 40 and 49 years & 0.201 & 0.255 & 0.934 & -0.50 & 0.90 \\
\hline & 50 years or more & -0.351 & 0.194 & 0.370 & -0.88 & 0.18 \\
\hline \multirow{4}{*}{$\begin{array}{l}\text { Between } 30 \\
\text { and } 39 \text { years }\end{array}$} & Less than 18 years & -0.873 & 0.353 & 0.099 & -1.84 & 0.09 \\
\hline & Between 19 and 29 years & -0.056 & 0.226 & 0.999 & -0.68 & 0.56 \\
\hline & Between 40 and 49 years & 0.145 & 0.309 & 0.990 & -0.70 & 0.99 \\
\hline & 50 years or more & -0.407 & 0.261 & 0.526 & -10.12 & 0.31 \\
\hline \multirow{4}{*}{$\begin{array}{l}\text { Between } 40 \\
\text { and } 49 \text { years }\end{array}$} & Less than 18 years & -1.018 & 0.372 & 0.051 & -2.04 & 0.00 \\
\hline & Between 19 and 29 years & -0.201 & 0.255 & 0.934 & -0.90 & 0.50 \\
\hline & Between 30 and 39 years & -0.145 & 0.309 & 0.990 & -0.99 & 0.70 \\
\hline & 50 years or more & -0.552 & 0.287 & 0.307 & -10.34 & 0.24 \\
\hline \multirow{4}{*}{$\begin{array}{l}50 \text { years or } \\
\text { more }\end{array}$} & Less than 18 years & -0.466 & 0.333 & 0.628 & -1.38 & 0.45 \\
\hline & Between 19 and 29 years & 0.351 & 0.194 & 0.370 & -0.18 & 0.88 \\
\hline & Between 30 and 39 years & 0.407 & 0.261 & 0.526 & -0.31 & 1.12 \\
\hline & Between 40 and 49 years & 0.552 & 0.287 & 0.307 & -0.24 & 1.34 \\
\hline
\end{tabular}

Source: own elaboration.

Therefore, beyond the differences by gender and age range not being significant, it is confirmed that social networks have become one of the main advertising strategies in companies (H1), that the expected objectives for mobile phone companies (H2) are obtained from social networks and that advertising on social networks does not work equally for all companies (H3); it is refused that social networks are an effective competitive tool in mobile phone companies (H4). In general, there is no correlation between sex and age and the impact of advertising on social networks for mobile phone manufacturers (H5). 


\section{Conclusions}

Social media are confirmed as a main advertising strategy, but improvement is needed in regards to their useful aspects as a tool for the advertising of mobile phone companies in Spain and for checking consumer behavior. They stand out in Samsung, Huawei, BQ, Xiaomi and Apple. The most used networks by companies are Facebook, YouTube, Twitter and Instagram. It is observed that brands usually choose to create a profile in social networks exclusive for each country.

Samsung, being a brand with a high degree of popularity, can allow less activity in social networks. Apple is betting on videos on the YouTube channel and photographs on Instagram, while Xiaomi and $\mathrm{BQ}$ opt for the strategy of being very active on their social networks and thus make themselves known to a wider audience.

The most used networks by users are Facebook and Instagram, and the brands with the most commercial impact, Apple and Samsung, are the best known as well. The quality of the product, the price and the experience itself are the factors that most influence the decision to purchase a smartphone. The rating of mobile phone advertising on social media is good, but it can be improved to reach the consumer behavior.

It is determined that there is no significant difference between the average rating of mobile phone advertising in social networks or in the influence of these by gender or by age ranges. However, the weight of social networks in telecom sector is increasing [28], taking in consideration the increase of information available to the consumers, especially thanks to the triple-play and the quintuple-play advance [24-27] and interactive options like HbbTV [5,9], because it fits the idea of conversation and engagement with the customers. Although we do not observe differences by gender or age, there is an increasing relationship created between follower and influencer [17].

As limitations of the research, the programs used in the analysis of social media cannot collect all the necessary information of each brand. Similarly, very different figures are obtained from social networks, since not all brands have a profile in Spain in each social network. The fact that a high number of respondents were concentrated in the same age range also determines the results. Hence, the calculation has taken into account the percentage of each gender and age without taking into account the number of participants of each. In the face of future research, it may be attractive to incorporate other geographical realities and issues linked to organic or natural positioning search engine optimization (SEO), payment and search engine marketing (SEM), in order to cross data.

In any case, the weight of social media in the advertising strategy of companies is confirmed, since they channel objectives expected by mobile telephony companies. The advertising inserted in social networks does not serve all companies equally, despite not detecting significant differences by gender and age. We can conclude that social media are an effective competitive tool in mobile phone companies, which should look for semantic social media marketing (SMM) solutions that help to make those investments profitable.

Author Contributions: Conceptualization, methodology and writing-original draft, J.-F.F.-G.; Investigation, survey preparation, data collection, P.M.-B.; Writing—review and editing, M.P.-L. and J.R.-R.; Funding, J.-F.F.-G., M.P.-L. and J.R.-R. All authors have read and agreed to the published version of the manuscript.

Funding: This research is part of the "New forms of interactive advertising on television, Internet and digital media. Real applications on HbbTV" project, financed by the Ministry of Economy, Industry and Competitiveness, reference CSO2017-88895-R (MINECO/FEDER).

Conflicts of Interest: The authors declare no conflict of interest.

\section{References}

1. Gershon, R.A. Media, Telecommunications, and Business Strategy; Francis \& Taylor Group: London, UK; New York, NY, USA, 2013.

2. Xataka Móvil. Ranking de Fabricantes de Telefonía Móvil; Xataka Móvil: Madrid, Spain, 2018. 
3. Hoffman, D.L.; Fodor, M. Can You Measure the ROI of Your Social Media Marketing? MIT Sloan Manag. Rev. 2010, 52, 41-49.

4. Fondevila-Gascón, J.F.; Mir-Bernal, P.; Rom-Rodríguez, J.; Santana-López, E.; Botey-López, J. Tendencias en métricas en medios sociales. Impacto en la publicidad. In Tendencias Publicitarias en Iberoamérica. Diálogo de Saberes y Experiencias; Zacipa-Infante, I., Tur-Viñes, V., Segarra-Saavedra, J., Eds.; Colección Mundo Digital. Alicante, Universidad de Alicante: Alicante, Spain, 2016; pp. 155-170.

5. Fondevila-Gascón, J.F.; Botey-López, J.; Rom-Rodríguez, J.; Muñoz-González, M. Posibilidades comunicativas del HbbTV: Un nuevo escenario para la publicidad interactiva. In Publicidad y Convergencia Mediática. Nuevas Estrategias de Comunicación Persuasive; Castelló-Martínez, A., del Pino-Romero, C., Eds.; Egregius Ediciones: Sevilla, Spain, 2017; pp. 11-28. ISBN 978-84-946978-6-9.

6. OJD Interactiva. Datos de Marzo de 2018; OJD Interactiva: Madrid, Spain, 2018.

7. Tuten, T.L.; Solomon, M.R. Social Media Marketing; Sage: London, UK, 2017.

8. Senders, A.; Govers, R.; Neuts, B. Social Media Affecting Tour Operators' Customer Loyalty. J. Travel Tour. Mark. 2013, 30, 41-57. [CrossRef]

9. Fondevila-Gascón, J.F.; Botey-López, J.; Rom-Rodríguez, J. Formats emergents en televisió: Anàlisi comparativa d'aplicacions publicitàries interactives en HBBTV. Comun. Rev. De Recer. i d'Anàlisi (Soc. Catalana Comun.) 2017, 34, 67-81.

10. Fondevila-Gascón, J.F. El papel decisivo de la banda ancha en el Espacio Iberoamericano del Conocimiento. Rev. Iberoam. Cienc. Tecnol. y Soc.-CTS 2009, 2, 1-15.

11. Fondevila-Gascón, J.F.; Del Olmo, J.L. La interactividad y el multimedia en la prensa digital internacional: los casos de España y el Reino Unido. Bilbao: III Congreso Internacional de Ciberperiodismo y Web 2.0. 2011.

12. Fondevila-Gascón, J.F. “La prensa digital en España: ¿un negocio viable para emprendedores?”. In El periodismo digital analizado desde la investigación procedente del ámbito académico; Sabés, F., Verón, J.J., Eds.; Asociación de la Prensa de Aragón: Huesca, Spain, 2012; pp. 231-243.

13. Fondevila-Gascón, J.F.; Carreras-Alcalde, M.; Del Olmo, J.L. Fuentes de información y elección de universidad: el caso catalán. Didáctica Innovación y Multimed. 2012, 8, 24.

14. Campos-Freire, F. Las redes sociales trastocan los modelos de los medios de comunicación tradicionales. Rev. Lat. Comun. Soc. 2008, 63, 277-286.

15. De Salas Nestares, M.I. La publicidad en las redes sociales: De lo invasivo a lo consentido. Icono 2010, 8, 5. [CrossRef]

16. Castelló, A.; Del Pino, C. La comunicación publicitaria con influencers. Rev. Académica Mark. Apl. 2015, 14, 21-50.

17. Geirinhas, G.G.A. Social Media: The New Tool in Firms' Marketing Strategies; NOVA-School of Business and Economics: Lisboa, Portugal, 2014.

18. Findlay, R. The short, passionate, and close-knit history of personal style blogs. Fash. Theory 2015, 19, 157-178. [CrossRef]

19. Kerr, G.F.; Mortimer, K.; Dickinson, S.; Waller, D. Buy, Boycott Or Blog Exploring Online Consumer Power to Share, Discuss and Distribute Controversial Advertising Messages. Eur. J. Mark. 2012, 46, 387-405. [CrossRef]

20. Bowman, S.; Willis, C. Nosotros, el Medio; The Media Center at the American Press Institute: Reston, VA, USA, 2005.

21. Gangadharbatla, H. Facebook me: Collective self-esteem, need to belong, and Internet self-efficacy as predictors of the iGeneration's attitudes toward social networking sites. J. Interact. Advert. 2008, 8, 5-15. [CrossRef]

22. Ramos, M. Publicidad e Internet: Una Oportunidad Para Conversar con el Usuario; Los libros de la Frontera Comunicación: Madrid, Spain, 2011.

23. Cerezo, J.M. Hacia un nuevo paradigm: La era de la información fragmentada. Telos 2008, 76, 91-98.

24. Fondevila-Gascón, J.F. Las redes de telecomunicaciones de cable histórico: Realidad y tendencias. Rev. De Comun. De La SEECI (Soc. Española Estud. Comun. Iberoam.) 2004, 11, 67-89.

25. Fondevila-Gascón, J.F. La televisión IP (IPTV) y la transmisión mediante VDSL: Realidad y perspectivas de negocio. Vivat Acad. 2009, 105, 59-87. [CrossRef]

26. Fondevila-Gascón, J.F. La adaptación regulatoria de los operadores de cable histórico en Spain. La competencia de los grandes operadores Older Cable Operators Adapt to New Regulations in Spain. Competition for Large Cable Operators. Telos. Cuad. Comun. Innovación 2009, 80, 139-146. 
27. Fondevila-Gascón, J.F. El peso de la televisión en el triple play de los operadores de cable en Spain y en Europa. Zerrevista Estud. Comun. (J. Commun. Stud.) 2009, 14, 13-31.

28. Bronner, F.; de Hoog, R. Social media and consumer choice. Int. J. Mark. Res. 2013, 56, 51-71. [CrossRef]

29. Blackwell, R.D.; Miniard, P.W.; Engel, J.F. Consumer Behavior, 10th ed.; Thomson South-Western: Boston, MA, USA, 2006.

30. Firat, A. A critique of the orientations in theory development in consumer behavior: Suggestions for the future. Adv. Consum. Res. 1985, 12, 3-6.

31. Jacoby, J. ACR presidential address consumer research: Telling it like it is. Adv. Consum. Res. 1976, 3, 1-11.

32. Belk, R.W. Possessions and the extended self. J. Consum. Res. 1988, 15, 139-168. [CrossRef]

33. Douglas, M.; Isherwood, B. The World of Goods: Towards an Anthropology of Consumption; Routledge: London, UK, 1979.

34. Firat, A.F.; Dholakia, N.; Venkatesh, A. Marketing in a postmodern world. Eur. J. Mark. 1995, $29,40-56$. [CrossRef]

35. Bauman, Z. Vida de Consumo; Fondo de Cultura Económica: Madrid, Spain, 2007.

36. Chernatony, L.; McDonald, M. Creating Powerful Brands; Elsevier: Oxford, UK, 2003.

37. Belk, R.W. Extended self in digital world. J. Consum. Res. 2013, 40, 477-500. [CrossRef]

38. Csikszentmihalyi, M.; Rochberg-Halton, E. The Meaning of Things: Domestic Symbols and the Self; Cambridge University Press: London, UK, 1981.

39. Muniz, A.; O'Guinn, T. Brand community. J. Consum. Res. 2001, 27, 412-432. [CrossRef]

40. Schouten, J.W.; McAlexander, J.H. Subcultures of consumption: An etnography of the new bikers. J. Consum. Res. 1995, 22, 43-61. [CrossRef]

41. Solomon, M.R. Mapping product constellations: A social categorization approach to consumption symbolism. Psychol. Mark. 1988, 5, 233-258.

42. Firat, A.F.; Shultz, C.J. From segmentation to fragmentation. Market and marketing strategy in the postmodern era. Eur. J. Mark. 1997, 31, 183-207. [CrossRef]

43. Holt, D. How consumers consume: A typology of consumption practices. J. Consum. Res. 1995, 22, 1-16. [CrossRef]

44. Ventakesh, A. Postmodernism perspectives for micromarketing. J. Macromarketing 1999, 19, 153-169.

45. McCracken, G. Culture and consumption: A theorical account of the structure of the cultural meaning of consumer goods. J. Consum. Res. 1986, 13, 71-83. [CrossRef]

46. Solomon, M.R. The role of products as social stimuli: A symbolic interactionism perspective. J. Consum. Res. 1983, 10, 319-329. [CrossRef]

47. Solomon, M.R.; Assael, H. The forest or the trees? A Gestalt approach to symbolic consumption. In Marketing and Semiotics: New Directions in the Study of Signs for Sale; Umiker-Sebeok, J., Ed.; Mouton de Gruyter: Berlin, Germany, 1987; pp. 189-217.

48. Aaker, J.; Benet-Martínez, V.; Garolera, J. Consumption Symbols as Carriers of Culture: A Study of Japanese and Spanish Brand Personality Constructs. J. Personal. Soc. Psychol. 2001, 81, 492-508. [CrossRef]

49. Holt, D. Poststructuralist lifestyle analysis: Conceptualizing the social of consumption in productivity. J. Consum. Res. 1997, 23, 326-350. [CrossRef]

50. Muniz, A. Consumers and brand meaning: Brands, the self and others. Adv. Consum. Res. 1997, 24, 308-309.

51. Comer, J.C.; Wikle, T.A. Worldwide diffusion of the cellular telephone (1995-2005). Prof. Geogr. 2008, 60, 252-269. [CrossRef]

52. Fondevila-Gascón, J.F. Periodismo ciudadano y cloud journalism: Un flujo necesario en la Sociedad de la Banda Ancha. Comun. y Hombre 2013, 9, 25-41. [CrossRef]

C 2020 by the authors. Licensee MDPI, Basel, Switzerland. This article is an open access article distributed under the terms and conditions of the Creative Commons Attribution (CC BY) license (http://creativecommons.org/licenses/by/4.0/). 